\title{
A Comparative Histological Study on the Effect of Adipose-Derived Stem Cells versus Their Conditioned Medium on Indomethacin Induced Enteritis in Adult Female Albino Rats
}

\author{
Original $\quad{ }^{1}$ Abeer F. Abdel Mohsen, ${ }^{1}$ Nagla M. Salama, ${ }^{2}$ Laila A. Rashed, ${ }^{1}$ Eman A. Farag \\ Article and ${ }^{1}$ Asmaa M. Abdel Hameed
}

${ }^{1}$ Histology Department, ${ }^{2}$ Biochemistry Department, Faculty of Medicine Cairo University, Cairo, Egypt

\begin{abstract}
Background: Inflammatory bowel disease (IBD), including Crohn's disease (CD), is a chronic complex immune-inflammatory disorder with increasing prevalence and inadequate conventional treatment.

Aim of work: Evaluating the therapeutic effect of adipose-derived mesenchymal stem cells (ADSCs) versus ADSCconditioned medium (CM) in a rat model of enteritis (CD).

Materials and Methods: Fifty-six female albino rats were used, 16 rats served as control (group I). In the remaining 40 rats, enteritis was induced by SC injection of 2 doses of indomethacin $7.5 \mathrm{mg} / \mathrm{kg}$, on days 0 and 1 of the experiment. After 10 days, rats were divided equally into 5 groups: Groups II and III received no further treatment and sacrificed at days 10 and 24 respectively. Groups IV,VandVI with ADSCs $(1 \times 106$ cells, IV single dose $)$, ADSC-CM (0.5mlintraperitoneal (IP), 5 doses) and DMEM $(0.5 \mathrm{ml}$ IP, 5 doses) respectively; they were all sacrificed at day 24 . Ileum specimens were stained with HandE, Masson's trichromeandAlcian blue/ PAS stains as well as MMP1 and PCNA immunostains.Morphometric measurements of area \% of collagen and MMP1, number of goblet cells and PCNA positive cells as well as optical density of Alcian blue/ PAS reaction were taken and statistically analyzed.

Results: Groups II, III and VI revealed obvious damage of villi and crypts, desquamation of epithelium, oedema and obvious mononuclear cellular infiltration together with significant decrease in number of goblet cells and PCNA +ve cells as well as in the optical density of Alcian blue/ PAS reaction and significant increase in the area $\%$ of collagen (in groups IIIandVI) and MMP1 as compared to control. Groups IV and V nearly regained the normal histological structure of villi and crypts.

Conclusion: ADSC-CM was as effective as ADSCs in reducing tissue fibrosis and in enhancing proliferation and mucosal regeneration in a rat model of enteritis $(\mathrm{CD})$.
\end{abstract}

Received: 10 July 2018, Accepted: 29 August 2018

Key Words: ADSCs, conditioned medium, crohn's disease, enteritis, indomethacin.

Corresponding Author: Asmaa M. Abdel Hameed, MSc., Department of Histology, Faculty of Medicine, Cairo University, Egypt, Tel.: +20 1090304335, E-mail: alabd.alsaleh@yahoo.com

ISSN: $1110-0559$, Vol. 41, No. 4

\section{INTRODUCTION}

Inflammatory bowel disease is a chronic complex pathological immuno-inflammatory response with increasing prevalence. It is a consequence of the improper and continuous activation of the mucosal immune system sustained by physiological flora ${ }^{[1]}$. CD is a major type of IBD that affects any part of the gastrointestinal tract (GIT), especially the terminal ileum. It has chronic progressive course which may lead to stricturing and bowel fistula with frequent terminal need for intestinal resection ${ }^{[2]}$. The current guidelines for conventional IBD therapy recommend the use of aminosalicylates, corticosteroids, or immunosuppressive drugs to treat symptoms and to prevent relapses $^{[3]}$. However, these therapies exhibit inadequacies in efficacy and have many side effects, especially with the use of immunosuppressants ${ }^{[4]}$.Accumulating evidence in animal and human studies has demonstrated that Mesenchymal stem cells (MSCs) may be used for the IBD treatmentdue to itsimmunomodulatory propertie ${ }^{[5,6]}$.

ApplicationofADSCs is a novel approach for enhancing regeneration or repair of damaged tissues particularly in an environment which is unfavorable for wound healing as Crohn's-related rectovaginalor perianal fistula. It has been hypothesized that the therapeutic effect of ADSCs may be due to their immunoregulatory and anti-inflammatory properties, which may work together to accelerate healing ${ }^{[7]}$.Although application of MSCs has shown beneficial effects in the therapy of autoimmune and chronic 
inflammatory diseases, the clinical application of stem cells still raises numerous ethical and safety concernswiththe ability to promote tumor growth and metastasis and overestimated therapeutic potential of MSCs. Thus, there is a strong need for more safe approaches to be used in the disease management ${ }^{[8]}$. MSCs can modulate inflammation and promote the regeneration of injured tissues through the secretion of factors that is called CM rather than by direct engraftment and differentiation ${ }^{[9]}$. The Mesenchymal stem cell-conditioned medium (MSC-CM) contains different kinds of cytokines and growth factors that have anti-inflammatory, immune regulation and stimulating regeneration effects. Thus, it may be a promising alternative to the direct administration of $\mathrm{MSCs}^{[10]}$. The aim of this study was to develop an experimental model of enteritis (Crohn's disease) using indomethacin in adult female albino rat. On such model, the possible therapeutic regenerative effect of both ADSCs and their conditioned mediumwas evaluated and compared. This was achieved by histological, immunohistochemicaland morphometric studies.

\section{MATERIALS AND METHODS}

\section{I) Animals:}

Fifty six female albino rats (190- $200 \mathrm{gm}$ ) were treated according to Cairo University Animal Use Committee guidelines. They were housed at the animal house, Faculty of Medicine, bred in wire mesh cages at and normal light/ dark cycle and provided with ordinary rat chow with free water and food access. The start of the study was designed as day 0 .

\section{II) Experimental design:}

\section{The rats were divided into 5 groups:}

Group I (control group, 16 rats): received SC injection of $0.06 \mathrm{ml}$ of saline on two consecutive days $24 \mathrm{~h}$ apart (days 0 and 1 ) and left till day 10 . The rats were divided into 4 subgroups( 4 rats each):

Subgroup IA: served as control for group II. Rats were sacrificed at day 10 .

Subgroup IB: served as control for group III, were left without further treatment. They were sacrificed at day 24 .

Subgroup IC: served as control for group IV, were injected at day 10 with $0.1 \mathrm{ml}$ PBS via the tail vein. They weresacrificed at day 24.

Subgroup ID: served as control for groups V and VI, were injected IP with $0.5 \mathrm{ml}$ Dulbecco's modified Eagle's medium (DMEM) for 5 consecutive days (days 10-14). They weresacrificed at day 24 .

\section{Induction of enteritis model:}

Forty rats were injected SC with indomethacin (Liometacin; in the form of powder $50 \mathrm{mg}$ dissolved in $2 \mathrm{ml}$ saline) at a dose of $7.5 \mathrm{mg} / \mathrm{kg}$ (i.e $1.5 \mathrm{mg}$ indomethacin dissolved in $0.06 \mathrm{ml}$ saline/rat), two doses $24 \mathrm{~h}$ apart (days 0 and 1$)^{[11]}$. They werethen left for 10 days and at day 10 they were divided into5 groups:

Group II (Indomethacin induced enteritis, 8 rats): sacrificed at day 10 .

Group III (Recovery group, 8 rats):rats were left without further treatment, the rats were sacrificed at day 24 .

Group IV (Stem cell-treated group, 8 rats): rats were injected at day 10 with $1 \times 106$ cells $/ 0.5 \mathrm{ml}$ PBS (PBS, GIBCO, NY, USA) IV via the tail vein ${ }^{[12]}$. The rats were sacrificed at day $24^{[13]}$.

Group V (ADSC-CM-treated group, 8 rats): rats were injected IP with $0.5 \mathrm{ml}$ of "culture $\mathrm{CM}$ afterinterferon gamma (IFN $₫)$ stimulation"/ day for five consecutive days (days 10-14) ${ }^{[14]}$. The rats were sacrificed at day 24 .

Group VI (DMEM treated group): rats were injected IP with $0.5 \mathrm{ml}$ of DMEM/day for five consecutive days (days 10-14). The rats were sacrificed at day 24 .

Body weight of the rats was recorded at days 0,10 and 24. The change in stool consistency, presence of blood in stool and increase the frequency (as determined by the need to change the animal cage) were observed.

At the end of experiment, the rats were sacrificedunder anaesthesiabyIP injection of ketamine $(90 \mathrm{mg} / \mathrm{kg}) / \mathrm{xylazine}$ $(15 \mathrm{mg} / \mathrm{kg})^{[15]}$. A midline abdominal incision was made and the abdomen was opened. The small intestine was dissected and the ileum (a segment about $1.5 \mathrm{~cm}$ proximal to the cecum) was excised. The specimens were fixed in $10 \%$ buffered formalin solution for 24 hours, dehydrated in ascending grades of ethanol and embedded in paraffin. Serial sections of $7 \mu \mathrm{m}$ thickness were cut and subjected to the followings:

1. Fluorescent microscope for detection of PKH26labeled ADSCs in unstained sections ${ }^{[16]}$

2. Hematoxylinand eosin (HandE) stain ${ }^{[17]}$

3. Masson's trichromestain for demonstration of collagen fibres ${ }^{[18]}$

4. Alcian blue / Periodic acid Schiff's (PAS) stainfor demonstration of mucus in gobletcells ${ }^{[17]}$

5. Immunohistochemichal staining ${ }^{[19]}$ for matrix metalloproteinase 1(MMP1). (Rabbit monoclonal primary antibody Novusbiologicals Corporation, CA, USA, Catalog Number: 110-57211)It is one of intestinal proteases that indicates excessive degradation of extracellular matrix $(\mathrm{ECM})^{[20]}$

6. Immunohistochemical staining ${ }^{[19]}$ forproliferating cell nuclear antigen (PCNA) (Mouse monoclonal antibody IHC WorldCorporation,CA, USA, Catalog Number:SC-56) as a marker of cell proliferation $^{[21]}$

The sections for immunohistochemical stains were boiled for $10 \mathrm{~min}$ in $10 \mathrm{mM}$ citrate buffer (AP9003) at $\mathrm{pH} 6$ for antigen retrieval then incubated for $1 \mathrm{~h}$ with the primary 
antibodies. Ultravision detection system (TP-015-HD) was used to complete immunostaining and Mayer'shematoxylin (TA-060-MH) was used for counterstaining. Citrate buffer, Ultravision detection system and Mayer's hematoxylin were purchased from Labvision Thermo Scientific, Fremont, California, USA.

Negative controls were done by applying same steps but omitting the step of adding the primary antibodies

Positive reaction appears as brown deposits in the extracellular matrix and in the cytoplasm for(MMPI) and as brown nuclear reaction for(PCNA).

\section{III) ADSCs isolation and culture: ${ }^{[22]}$}

Isolation ofADSCs from rat abdominal subcutaneous fat and their culture and labeling with PKH26 and preparation of ADSC-CM, were performed at the Unit of Biochemistry and Molecular Biology at Medical Biochemistry Department, Faculty of Medicine, Cairo University, Egypt.

Abdominal subcutaneous fat were collected and transferred into tube with PBS. The tissue was minced into small pieces. The extracellular matrix was digested by adding collagenase solution then incubation at $37{ }^{\circ} \mathrm{C}$ for 40min was done. Collagenase was inactivated by adding DMEM into the $50 \mathrm{ml}$ tube then centrifugation was done. The cell pellet was visible at the bottom of the tube. The supernatant was aspirated and the cell pellet was resuspendedin $20 \mathrm{ml}$ DMEM after centrifugation. The cell suspension was filtered and centrifugation was done. The cell pellet containing ADSCs was resuspended in $10 \mathrm{ml}$ DMEM, transferred onto cell culture flask and incubated at $37{ }^{\circ} \mathrm{C} / 5 \% \mathrm{CO} 2$ for $24 \mathrm{~h}$. After that, the adherent cells (ADSCs) were washed with PBS and were cultured in fresh proliferation medium until $70 \%$ confluence. Subculture of ADSCs were done till the third passage to expand cell population. After several days of culture, ADSCs showed a typical fibroblastic-like morphology.

\section{Cell surface markers staining and flow cytometry: ${ }^{[22]}$}

Isolated rat ADSCs were analyzed using the fluorescence activated cell sorter(FACS) hardware and software packages for data acquisition. Typically it was found that more than $98 \%$ of the isolated ADSCs express MSC markers, including CD90, CD44, CD29, CD73 and CD105. However, less than $1 \%$ of the isolated ADSCs express cell surface markers for hematopoietic cells (CD34, CD14, CD11b, and CD45) and markers for endothelial cells (CD31 and CD106).

ADSCs cells were harvested during the $3^{\text {rd }}$ passage and were labeled with PKH26 fluorescent linker dye. according to Sigma protocol steps. After labeling with PKH26, undifferentiated ADSCs were injected intravenously into rat tail vein.

VI)Adipose Stem Cell Conditioned Medium (ADSC-CM):

Rat ADSCs were seeded, and when they reached confluence $70 \%$, the medium was changed to a DMEM serum-free medium. The cells were exposed to $100 \mathrm{ng} / \mathrm{mL}$ rat IFN $₫$ for a continuous $24 \mathrm{~h}$ to provide preconditioning of ADSCs for production of cytokines. After that, ADSCs were washed with PBS and were further incubated in serum free DMEM for $24 \mathrm{~h}$. The conditioned media, which was designated as "culture CM after IFN $₫$ stimulation" were collected, centrifuged at $3000 \mathrm{~g}$ for $5 \mathrm{~min}$, and finally filtered then further concentration was done ${ }^{[14]}$.

\section{Morphometric study}

Ten non-overlapping fields from different sections of each ratof

each group were used to measure:

- Area percent of collagen (x400) .

- Number of goblet cells(x400)

- Optical density of alcian blue/PAS +ve reaction $(\mathrm{x} 400)$

- Area percent of MMP1(x400)

- $\quad$ Number of PCNA-positive cells. (x400)

Measurements were taken using "Leica Qwin 500 C" image analyzer computer system Ltd. (Cambridge, England). (Histology Department, Faculty of Medicine, Cairo University)

\section{Statistical analysis:}

Quantitative data were summarized as means and standard deviations (SD) and compared using one-way analysis-of-variance (ANOVA) and followed by post hoc Tukey test. $P$-values $<0.05$ were considered statistically significant. Calculations were made on SPSS software version $21^{[23]}$.

\section{RESULTS:}

\section{General observations:}

No deaths were recorded in all rats during the experiment.

All control subgroups showed similar histological results so, they were collectively named control group.

On day 10, animals in group I (control group) showed increased body weight. While animals in groups II, III, IV, V and VI showed significant loss of body weight as compared to control group. On day 24, animals treated with ADSCs in group IV and ADSC-CM in group V showed significant increase in body weight compared to group III (recovery group) and VI (DMEM treated group) and non significant difference as compared to each other. (Table 1 and Histogram 1)

In experimental groups starting from day 6 , the color of stools changed to black (indicating presence of blood). The stool frequency also increased from this time. In groups III and VI slight decrease in the stool frequency with minimal improvement of its color was noted by day 22 . On the other 
hand, animals of groups IV and V showed remarkable decrease in the stool frequency with obvious improvement in its color by day 17 .

\section{Histological results:}

- Fluorescence detection of PKH26 labeled ADSCs by fluorescent microscope:

Examination of PKH26-labelled ADSCs in unstained ileum sections revealed yellow fluorescence distributed within the villi (in the regenerated surface epithelium and CT corium), crypts as well as in the submucosa

- Hematoxylin and eosin stain: (Figs 1 and 2)

Examination of ileum sections from group I showed normal organization of villi and crypts, The epithelium covering the villi and lining the crypts was intact showing predominance of enterocytes with goblet cells scattered among them. The enterocytes appeared with its normal brush border. Continuous layer of muscularis mucosa with normal cellularity of the submucosa were also observed. Musculosa and adventitia appeared intact (Fig. 1 A)

Sections from group II revealed obvious disorganization and damage of some villi and crypts together with desquamation of the epithelium covering the villi. Obvious mononuclear cellular infiltration in mucosa and submucosa was also observed. Wide spaces in villus core were noted in certain areas. Widening of the crypts with distortion of the cells lining the crypts were frequently seen (Figs. $1 \mathrm{~B}$ and $\mathrm{C}$ ).

Groups III and VI revealed comparable results, ileum sections showed severe desquamation and damage of the epithelium covering the villi and severe destruction of the cells lining the crypts. Mononuclear cellular infiltration in both groups(Figs. 1dandf ). Mast cells in group III were detected in the villi core (Fig. 1E).

Meanwhile, groups IV and V showed remarkable improvement as most villi (Fig. 2 A and C)and crypts (Fig. $2 \mathrm{~B}$ and D)restored their architecture with normal distribution of enterocytes and goblet cells. However, mild mononuclear cellular infiltration of the lamina propria and wide spaces in the submucosa and in the CT core of few villi were still observed in group IV(Fig. 2 B).

- Masson's trichrome stain:(Fig. 3)

Examination of Masson'strichrome stained sections from group I showed fine collagen fibers in the CT core of villi and between the crypts. (Fig $3 \mathrm{~A}$ ).

In group II, fine collagen fibers were seen in the lamina propriaof the disrupted villi and in between the disorganized crypts (Fig. 3 B).

However, in groups III andVI obvious deposition of collagen in the lamina propria of the villi, in between the crypts and in thesubmucosa was detected (Fig $3 \mathrm{C}$ and $\mathrm{D}$ ). On the other hand, groups IV and V showed scattered collagen fibers in the lamina propriaof the villi core and in between the crypts(Fig. 3 E and F).

- $\quad$ alcain blue /PAS stain:(Fig. 4)

Control group showed strong intensity of alcain blue /PASreaction in the goblet cells and in the brush border of enterocytes(Fig 4 A).Groups II, III and VI showed few goblet cells withapparent weak intensity of the purple color of alcain blue/PASstain in most of the fields. Lost brush border of most enterocytes was seen(Fig 4 B, C and D). On the other hand, groups IV and V showed numerous goblet cells with apparent strong intensity of purple color. The brush border of most enterocytes in villi and crypts was preserved and well-stained (Figs $4 \mathrm{E}$ and F).

\section{- MMP1 immunohistochemicalstain:(Fig. 5)}

Control group, The CT core of the villus showed localized faint brown positive extracellular reaction. Positive intracellular reaction was also seen(Fig 5 A).Groups II, III and VI showed widespread dense positive MMP1 expression in the extracellular matrix in wide areas of the mucosa together with strong positive cytoplasmic reaction in some enterocytes (Fig. 5 B, C and D). Meanwhile, groups IV and V showed localized weak positive MMP1 expression in the extracellular matrix of the mucosa and in the cytoplasm of some enterocytes and CT cells. (Fig $5 \mathrm{E}$ and $\mathrm{F}$ ).

- PCNA immunohistochemicalstain: (Fig. 6)

Control group, showed positive nuclear immunoreactivity for PCNA in the villi core. Few enterocytes with positive immunoreactivity was also seen (Fig. 6 A). Groups II, III and VI revealed few PCNA +ve cells in the villi core (Fig $6 \mathrm{~B}, \mathrm{C}$ and D) and in crypts lining epithelium (Fig 6 D). On the other hand, groups IV and V showed numerous PCNA +ve cells in the CT corium of the villi. Some enterocytes also showed positive immunoreactvity (Fig. $6 \mathrm{E}$ and F).

\section{Morphometric and statistical results (Table 2 and Histograms 2- 6):}

There was significant increase in the mean area $\%$ of collagen in groups III and VI compared to control group or to group II. On the other hand, groups IV and V showed significant reduction in the mean area percent of collagen when compared to groups III and VI and non significant difference when compared to each other.

There was significant decrease in the mean number of goblet cells and in the optical density of the mucus in groups II, III and VI compared to control group. On the other hand, groups IV and V showed significant increase as compared to groups II, III and VI andnon significant difference when compared to each other or with the control group.

A significant increasein the mean area percent of MMP1 in groups II, III and VI was detected as compared to control group. However there was significant reduction in groups III and VI as compared to groups II. Also there 
was significant reduction in groups IV and $\mathrm{V}$ as compared to groups II, III and VI andnon significant difference when compared to each other.

The mean number of PCNA +ve cells in groups II, III and VI showed significant reductionas compared to control group. On the other hand, groups IV and V showed significant increase as compared to groups II, III and VI. While group V showed significant increase as compared to group IV.

Table 1: The mean body weight in grams ( \pm SD) of rats in the studied groups as recorded on day 0,10 and 24

\begin{tabular}{lllc}
\hline \multicolumn{1}{c}{ Group } & Day 0 & Day 10 & Day 24 \\
\hline Group I (control group & $192.0 \pm 1.0$ & $215.3 \pm 0.44$ & $251.6 \pm 2.2$ \\
Group II(Indomethacin induced enteritis) & $192.0 \pm 1.0$ & $194.7 \pm 0.74^{*}$ & - \\
Group III (recovery group) & $192.0 \pm 1.0$ & $194.7 \pm 0.74^{*}$ & $168.5 \pm 0.57^{\Omega}$ \\
Group IV (stem cell treated group) & $192.0 \pm 1.0$ & $194.7 \pm 0.74^{*}$ & $214.4 \pm 1.5^{\# \Omega}$ \\
Group V (ADSC-CM-teated group) & $192.0 \pm 1.0$ & $194.7 \pm 0.74^{*}$ & $216.8 \pm 1.8^{\# \Omega}$ \\
Group VI (DMEM-treated group) & $192.0 \pm 1.0$ & $194.7 \pm 0.74^{*}$ & $166.7 \pm 1.2^{\Omega}$ \\
\hline
\end{tabular}

*significant as compared to group I on day $10(p<0.05)$.

$\Omega$ significant as compared to group I on day $24(p<0.05)$.

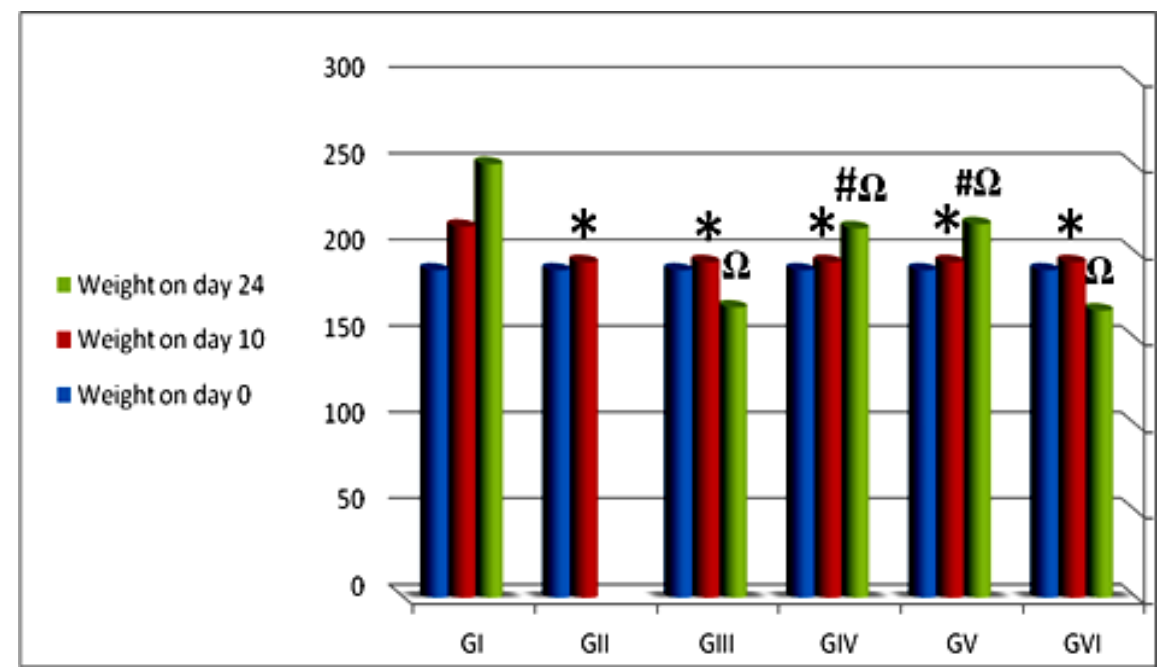

Histogram 1: Mean body weight in grams of rats in the studied groups as recorded on day 0,10 and 24 .

*significant as compared to group I on day $10 \quad(p<0.05)$.

$\Omega$ significant as compared to group I on day $24(p<0.05)$.

Table 2: Morphometric results

\begin{tabular}{|c|c|c|c|c|c|c|}
\hline & $\begin{array}{l}\text { Group I (control } \\
\text { group) }\end{array}$ & $\begin{array}{c}\text { Group } \\
\text { II(indomthacin } \\
\text { induced enteritis) }\end{array}$ & $\begin{array}{c}\text { Group III } \\
\text { (recovery group) }\end{array}$ & $\begin{array}{l}\text { Group IV (stem } \\
\text { cell treated group) }\end{array}$ & $\begin{array}{l}\text { Group V(ADSC- } \\
\text { CM-treated group) }\end{array}$ & $\begin{array}{l}\text { Group VI (DMEM } \\
\text { treated group) }\end{array}$ \\
\hline $\begin{array}{c}\text { Mean area \% } \\
\text { of collagen }\end{array}$ & $0.08 \pm 0.02$ & $0.07 \pm 0.01$ & $1.70 \pm 0.41^{* \Delta}$ & $0.1 \pm 0.03^{\#}$ & $0.09 \pm 0.02^{\#}$ & $1.38 \pm 0.46^{* \Delta}$ \\
\hline $\begin{array}{l}\text { Mean number } \\
\text { of goblet cells/ } \\
\operatorname{HPF}( \pm \mathrm{SD})\end{array}$ & $46.10 \pm 9.39$ & $8.00 \pm 2.00^{*}$ & $14.50 \pm 3.62^{*}$ & $44.30 \pm 13.07^{\Delta \#}$ & $42.20 \pm 8.63^{\triangle \#}$ & $13.90 \pm 3.84^{*}$ \\
\hline $\begin{array}{l}\text { Mean optical } \\
\text { density of alcian } \\
\text { blue } / \mathrm{PAS}+\mathrm{ve} \\
\text { reaction }( \pm \mathrm{SD})\end{array}$ & $0.89 \pm 0.05$ & $0.72 \pm 0.05^{*}$ & $0.70 \pm 0.05^{*}$ & $0.85 \pm 0.03^{\Delta \#}$ & $0.83 \pm 0.04^{\Delta \#}$ & $0.67 \pm 0.03^{*}$ \\
\hline $\begin{array}{l}\text { Mean area \% of } \\
\operatorname{MMP} 1( \pm \mathrm{SD})\end{array}$ & $0.29 \pm 0.08$ & $10.33 \pm 1.63^{*}$ & $8.41 \pm 0.75^{* \Delta}$ & $0.84 \pm 0.20^{\triangle \#}$ & $0.62 \pm 0.11^{\Delta \#}$ & $7.96 \pm 1.25^{* \Delta}$ \\
\hline $\begin{array}{c}\text { Mean number of } \\
\text { PCNA +ve cells/ } \\
\text { HPF }( \pm \text { SD })\end{array}$ & $36.4 \pm 8.83$ & $11.50 \pm 3.02^{*}$ & $14.70 \pm 4.42^{*}$ & $52.60 \pm 10.84^{* \#}$ & $79.80 \pm 17.86^{* \Delta \# \#}$ & $14.40 \pm 4.35^{*}$ \\
\hline
\end{tabular}

* significant as compared to group I $(p<0.05)$.

\#significant as compared to group III andVI $(p<0.05)$

$\Delta$ significant as compared to group II $(p<0.05)$.

$¥$ significant increase as compared to group IV $(p<0.05)$ 


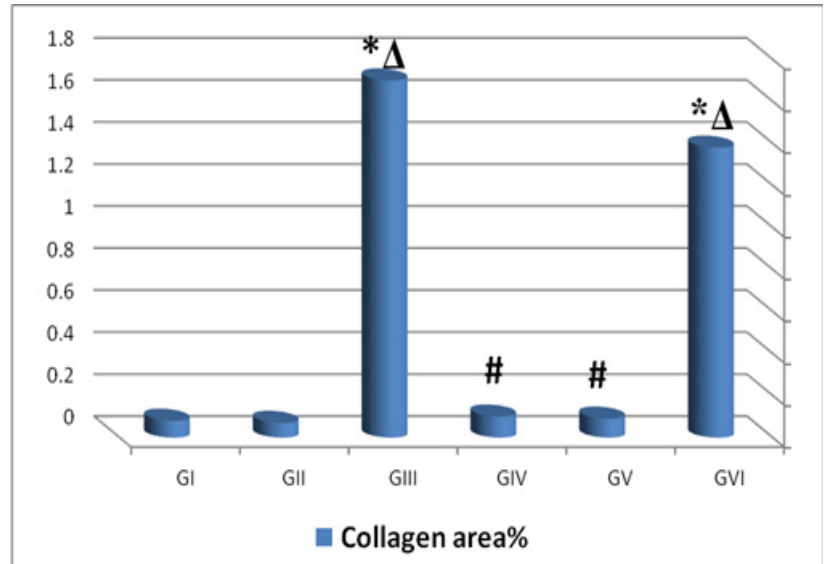

Histogram 2: Mean area percent of collagen in the studied groups.

* significant as compared to group I $(p<0.05)$

$\Delta$ significant as compared to group II $(p<0.05)$

\#significant as compared to group III andVI $(p<0.05)$

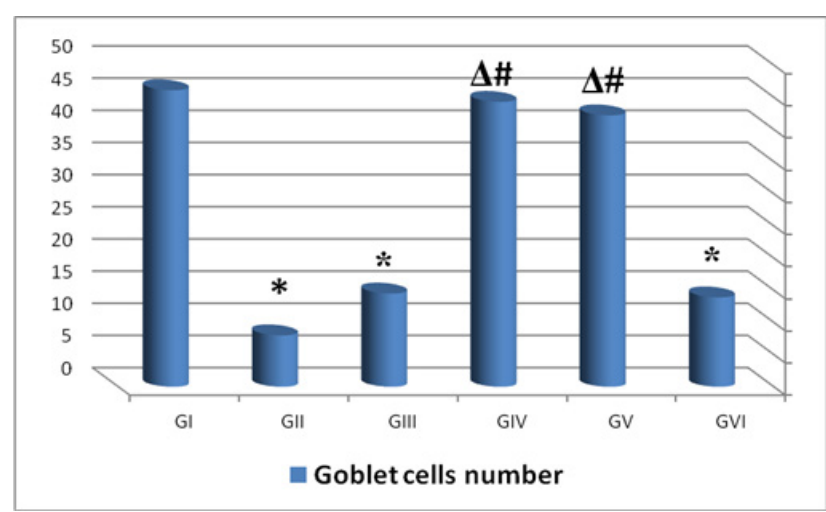

Histogram 3: Mean number of goblet cells/HPF in the studied groups

* significant as compared to group I $(p<0.05)$

$\Delta$ significant as compared to group II $(p<0.05)$

\#significant as compared to group III andVI $(p<0.05)$

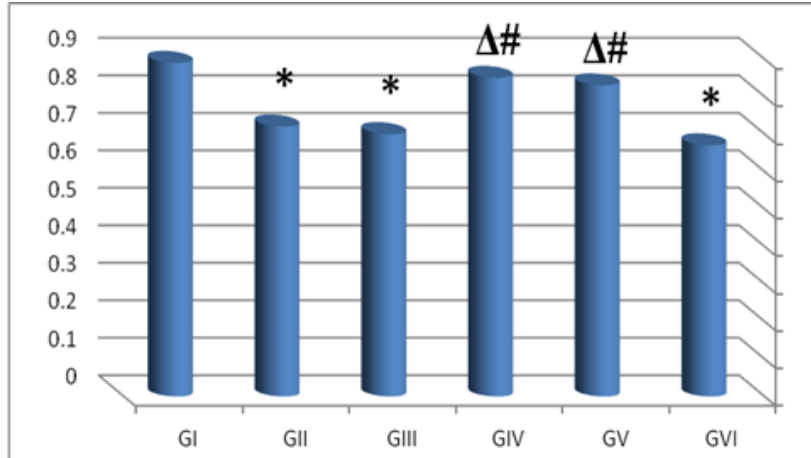

Optical density of alcian blue/PAS +ve reaction

Histogram 4: Mean optical density of alcian blue/PAS +ve reaction in the studied groups

* significant as compared to group I $(p<0.05)$

$\Delta$ significant as compared to group II $(p<0.05)$

\# significant as compared to group III and VI $(p<0.05)$

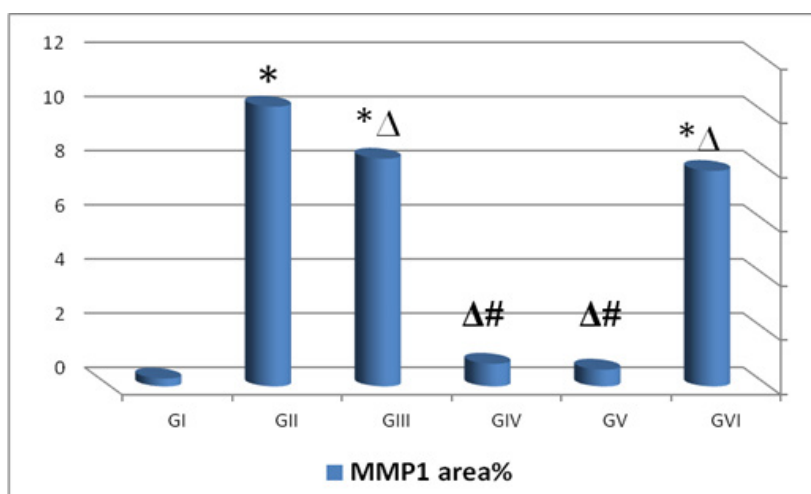

Histogram 5: Mean area percent of MMP1 in the studied groups

* significant as compared to group I $(p<0.05)$

$\Delta$ significant as compared to group II $(p<0.05)$

\#significant as compared to group III andVI $(p<0.05)$

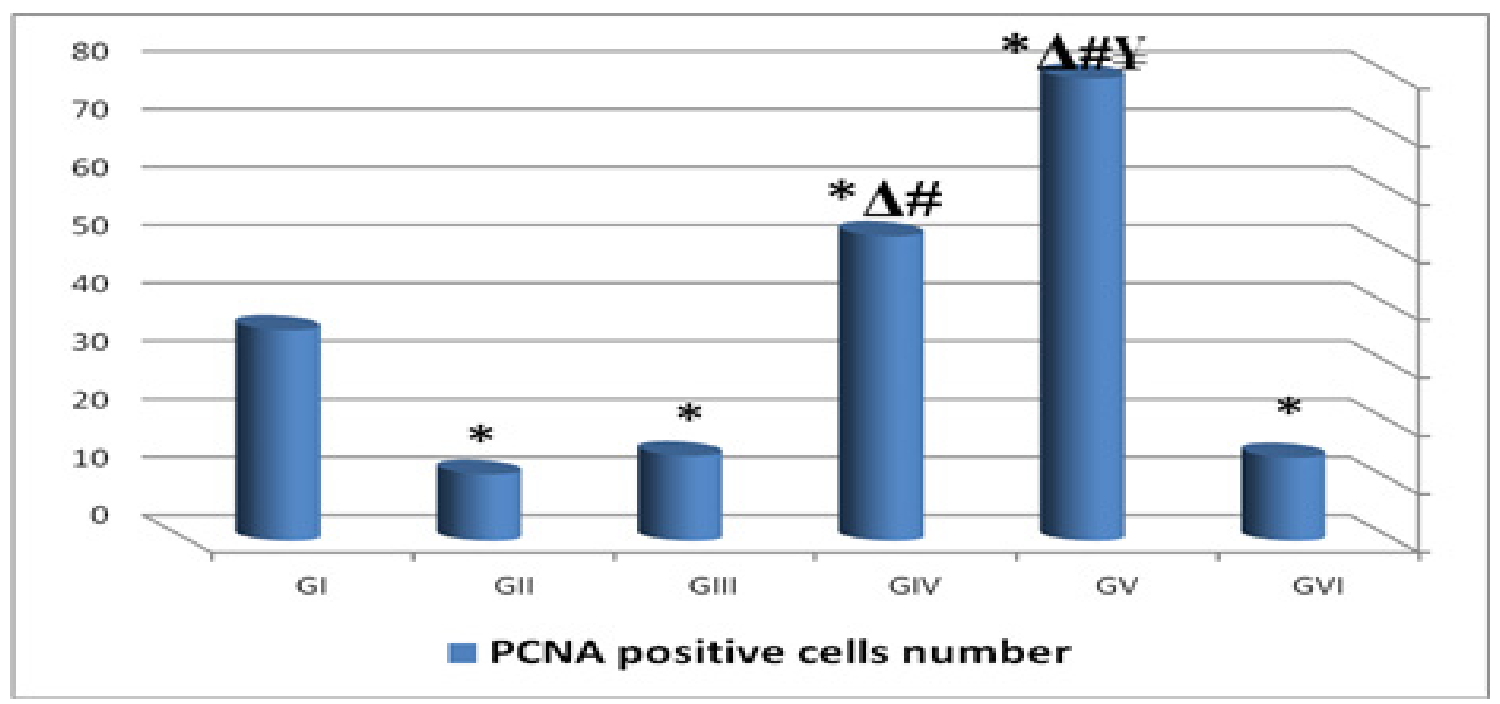

Histogram 6: Mean number of PCNA positive cells/HPF in the studied groups

* significant as compared to group I $(p<0.05)$

$\Delta$ significant as compared to group II $(p<0.05)$

\#significant as compared to group III andVI $(p<0.05)$

$¥$ significant increase as compared to group IV $(p<0.05)$ 


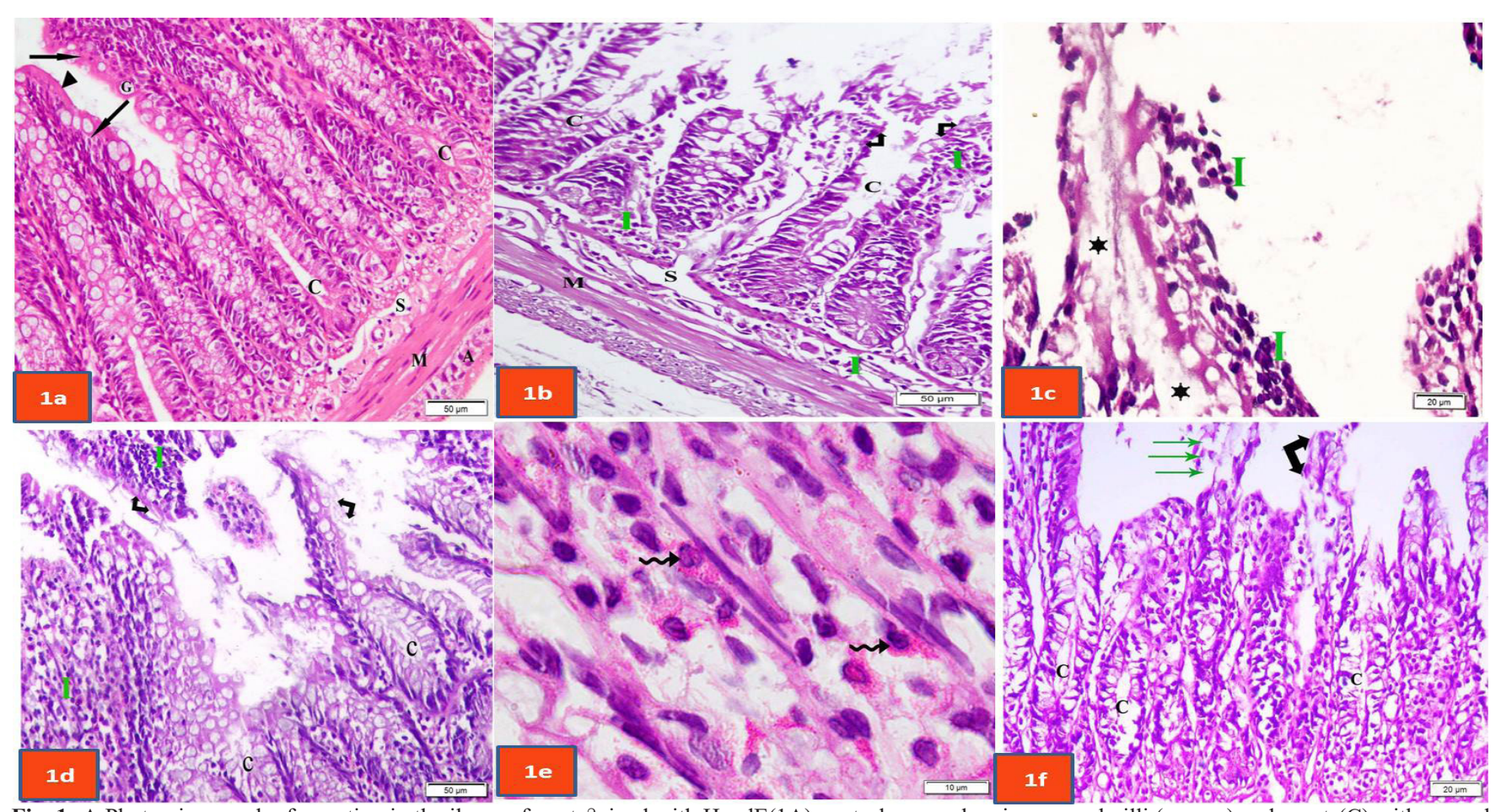

Fig. 1: A Photomicrograph of a section in the ileum of a rat stained with HandE(1A):control group showing normal villi (arrows) and crypts(C) with normal enterocytes (arrowhead) and goblet cells (G).Other layers appear normal (x200).(1B):group II showing disrupted villiwith desquamation of the epithelial covering (doubled arrows). The crypts(C) showed widening and destruction of the cell lining.Mononuclear cellular infiltration (I) in mucosa and submucosa (x200). (1C): group II showing mononuclear cellular infiltration (I).Wide spaces in the core of the villi (stars) (x400). (1D):group III showing disrupted villi with desquamation of the epithelium covering (doubled arrows) with disorganized crypts (C) and mononuclear cellular infiltration (I) (x200). (1E):group IIIshowing many mast cells (wavy arrows) (x1000). $(1 \mathrm{~F})$ :groupVIshowing severe destruction of the villi (green arrows) with desquamation of their covering epithelium (doubled arrow). The crypts (C) are deformed (x200).

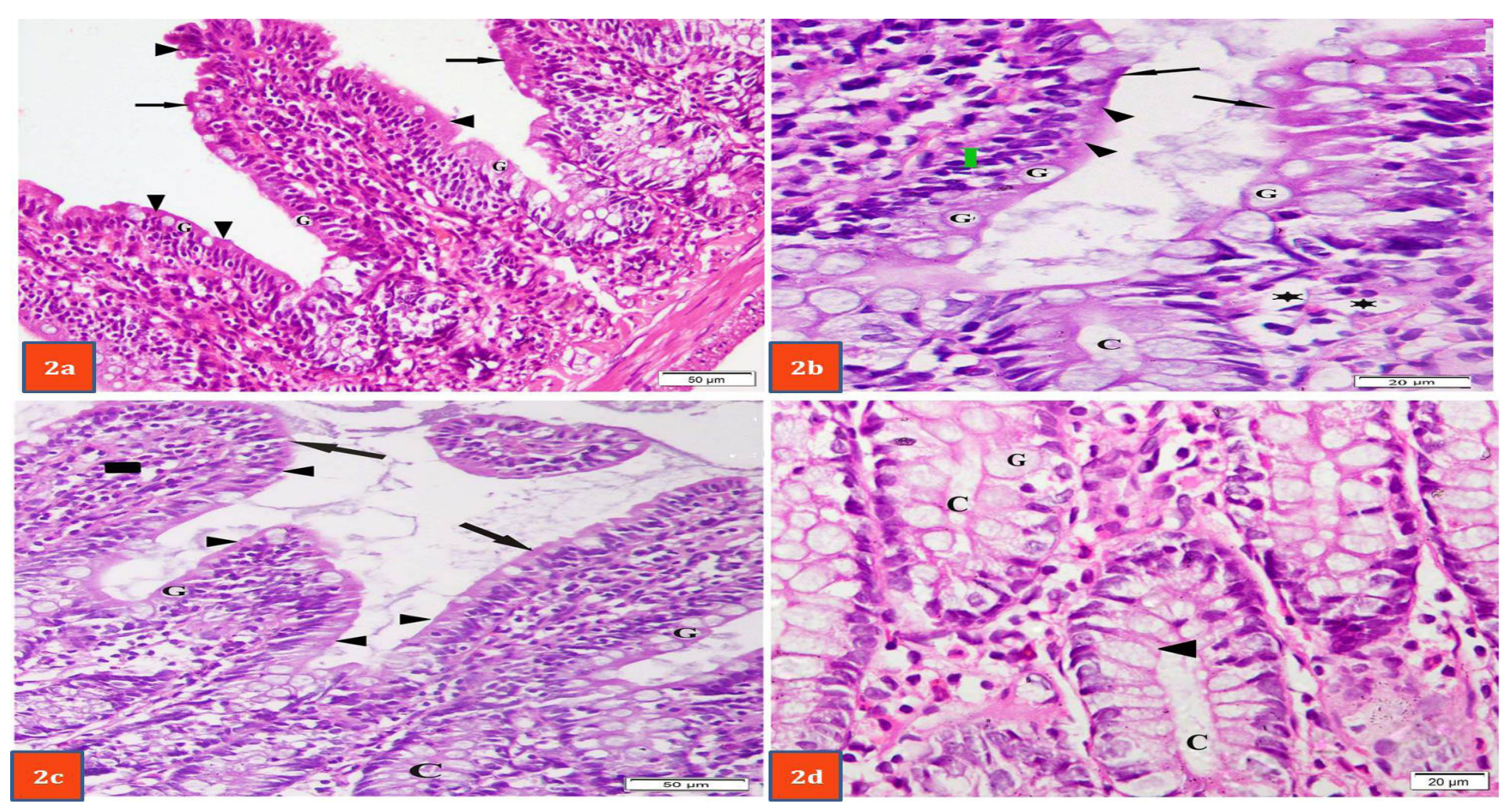

Fig. 2: A Photomicrograph of a section in the ileum of a rat stained withHandE (2A): groupIV,the villi (arrows) show normal architecture with normal distribution of enterocytes (arrowheads) and goblet cells (G) (x200). (2B): groupIV,the villi (arrows) show normal architecture with normal distribution of enterocytes (arrowheads) and goblet cells (G).Well organized crypts (C) are also seen. Cellular infiltration (I)and some wide spaces (stars) are noted in the core of villi (x400).(2C):groupV,the villi (arrows) show normal architecture with normal distribution of enterocytes (arrowheads) and goblet cells (G) and normal CT cellularity (square)(x200). (2D): groupV,well organized crypts (C) with normal cell lining, goblet cells (G) and enterocytes (arrow head) (x400). 


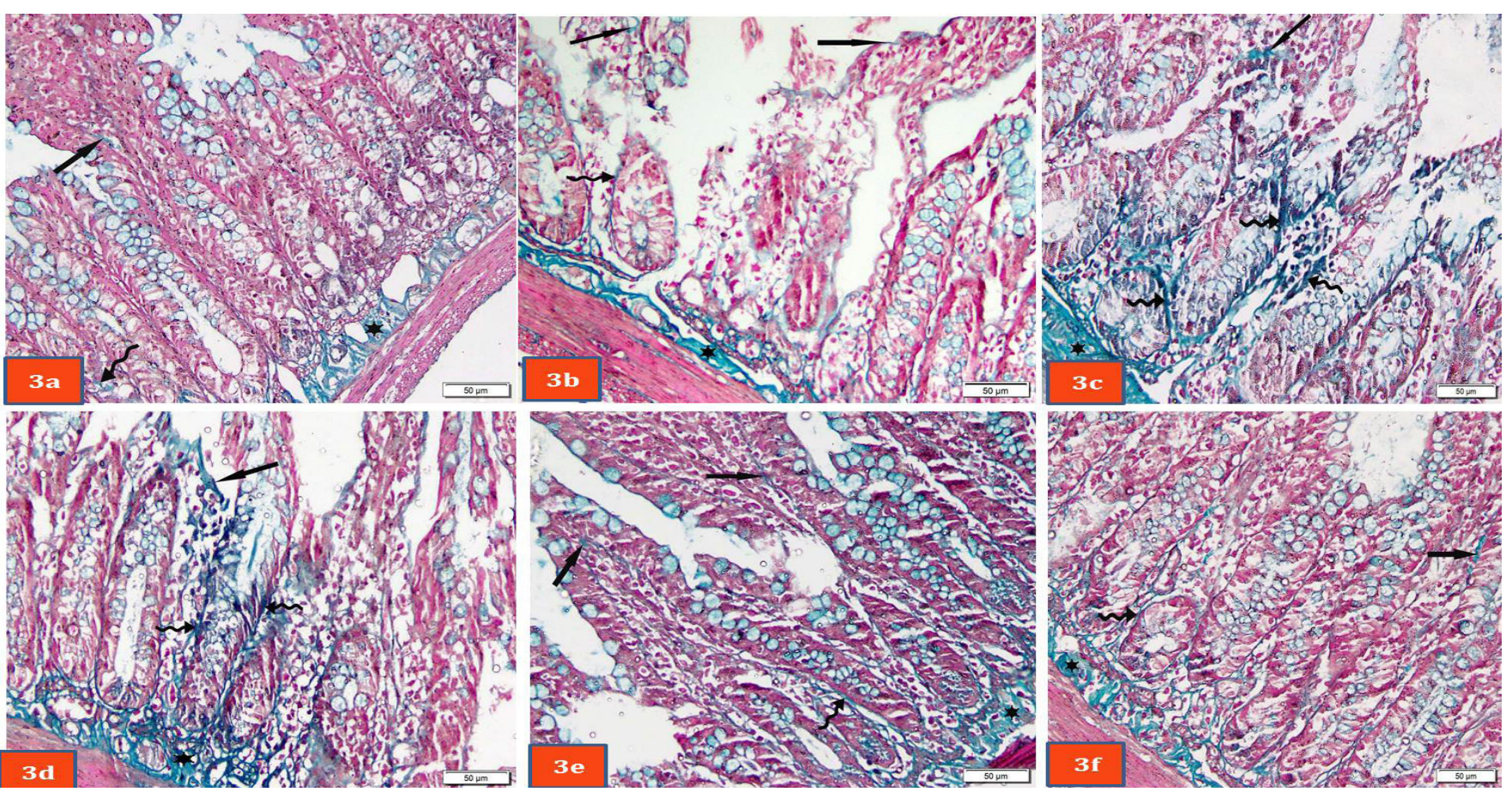

Fig. 3: A Photomicrograph of a section in the ileum of a rat stained with Masson's trichrome(3A): control group showing fine green stained collagen fibers in thevillus core (arrow) and in between the crypts (wavy arrow). More dense collagen fibers are seen in submucosa (star)(x200).(3B):group IIshowing fine green stained collagen fibers in the lamina propria of disrupted villi (arrows) and in between the crypts (wavy arrows). More dense collagen fibers are seen in the submucosa (star) (x200). (3C): group III showing widespread green-stained dense thick collagen fibers in the lamina propriaof the villi (arrow) and in between the crypts (wavy arrows). Obvious deposition of collagen is seen in thesubmucosa (star)(x200).(3D):groupVIshowing dense green-stained collagen bundles in the lamina propria of the villus core (arrow) and in between the crypts (wavy arrows). Deposition of collagen is seen in the submucosa (star)(x200).(3E):group IVshowing scattered green-stained collagen fibers in the lamina propriaof the villi core (arrows) and in between the crypts (wavy arrow)More dense collagen is seen in the submucosa (star)(x200).(3F):group V,scattered green-stained collagen fibers in the lamina propriaof the villus core (arrow) and in between the crypts (wavy arrow). Note collagen fibers in the submucosa (star)(x200).

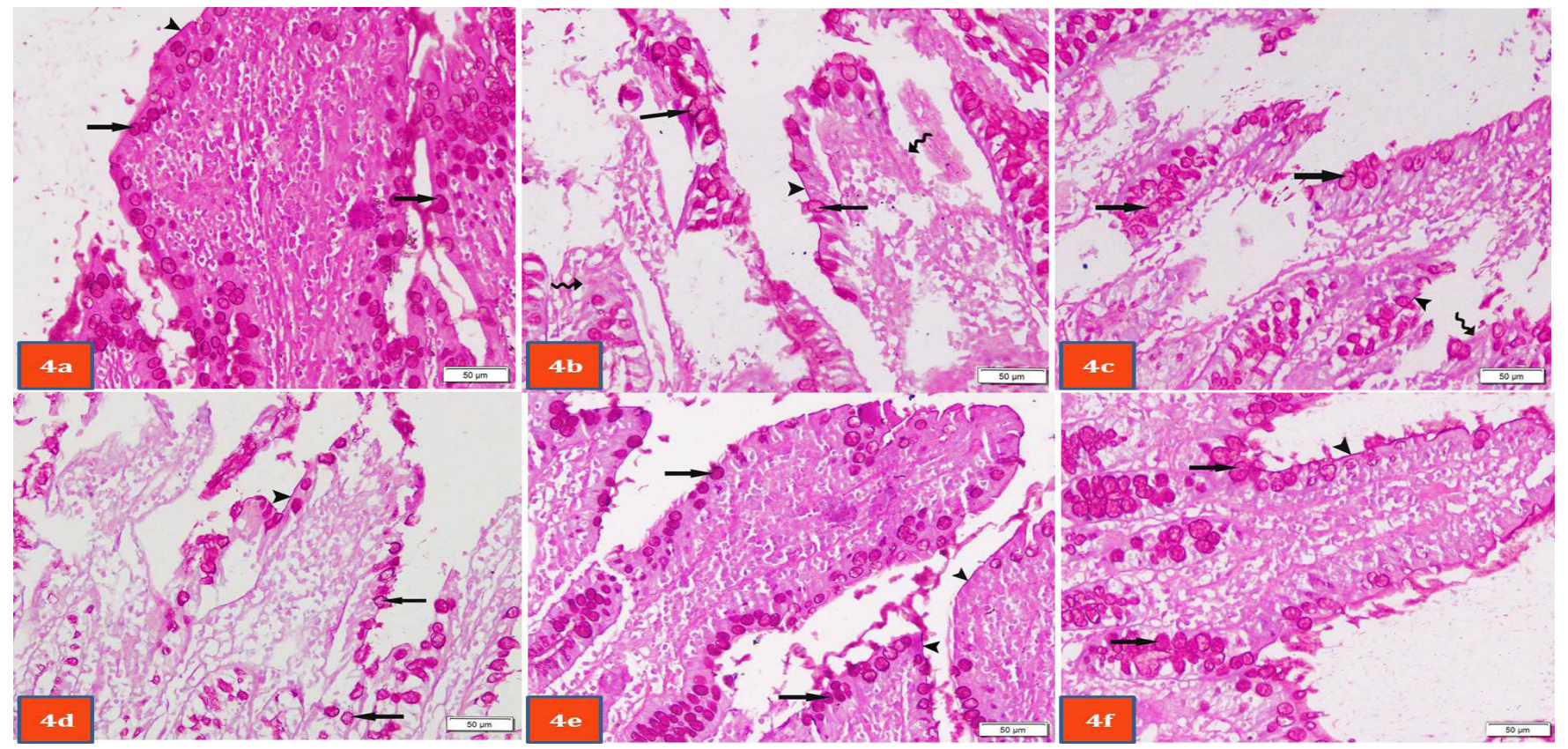

Fig. 4: A Photomicrograph of a section in the ileum of a ratstained withAlcain blue /PAS(4A):control group showing strong intensity of alcain blue /PAS reaction in the goblet cells (arrows) and in the brush border of enterocytes (arrowhead)(x200).(4B): group IIshowing apparently few goblet cells with apparent weak intensity of alcain blue /PAS stain (arrows). Lost brush border of most enterocytes (wavy arrows) but preserved well-stained brush border in few enterocytes are seen (arrowhead)(x200).(4C): group III,apparently few goblet cells in villi and crypts with apparent weak intensity of alcain blue/PAS stain (arrows). Brush borders of most enterocytes are lost (wavy arrow). Preserved well-stained brush borders are seen in few enterocytes (arrowhead)(x200).(4D): groupVI,apparently few goblet cells; most of them exhibit apparent weak intensity of alcain blue/PAS stain (arrows). Only few enterocytes with preserved well-stained brush border are seen (arrowhead)(x200).(4E): group IVshowing numerous goblet cells with an apparent strong intensityof alcain blue/PAS stain (arrows). The brush borders of most enterocytes are preserved and well-stained (arrowheads)(x200).(4F):groupV, numerous goblet cells with apparent strong intensity of alcain blue/PAS stain(arrows). The brush border of most enterocytes is preserved and well-stained (arrowhead)(x200). 


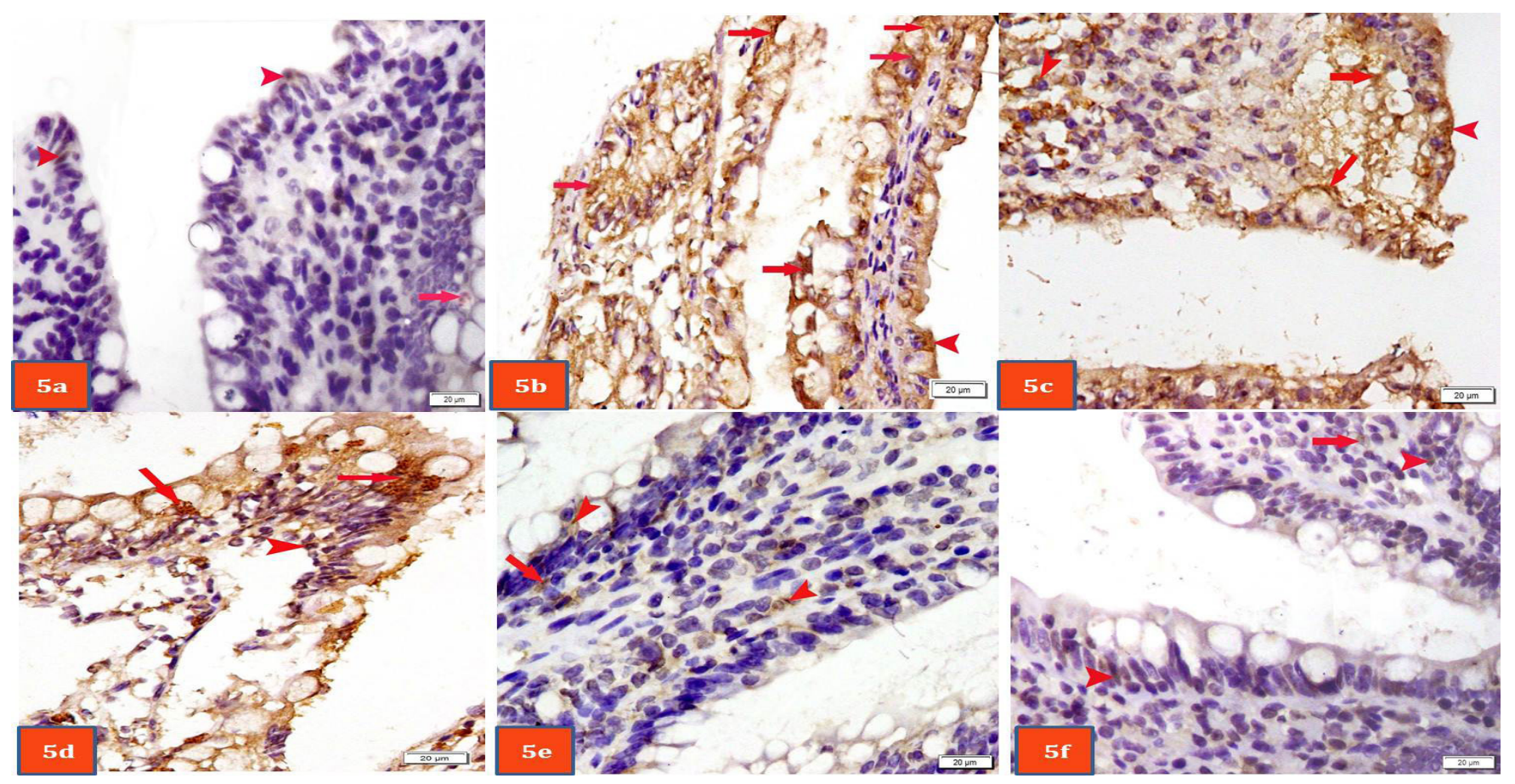

Fig. 5: A Photomicrograph of a section in the ileum of a ratstained with MMP1 immunostaining $(5 \mathrm{~A})$ : control group, The CT core of the villus shows localized faint brown positive extracellular reaction (arrow). Positive intracellular reaction can also be seen (arrowheads) (x400).(5B): groupIIshowing widespread dense positive immunoreactivity for MMP1 in the extracellular matrix of the villi (arrows). Strong positive cytoplasmic reaction is also seen in some enterocytes (arrowhead)(x400).(5C): group III,The CT core of the villus shows widespread positive immunoreactivity for MMP1 in the extracellular matrix (arrows) Strong positive cytoplasmic reaction (arrowheads) is also detected in both enterocytes and CT cells (x400). (5D):groupVI, disrupted villus with widespread positive immunoreactivity for MMP1 in the extracellular matrix (arrows) with some positive intracellular cytoplasmic reaction (arrowhead)(x400).(5E):group IVshowing localized weak positive immunoreactivity for MMP1 in the extracellular matrix (arrow). Weak positive cytoplasmic reaction (arrowheads) in few enterocytes and CT cells is seen (x400).(5F):groupV localized faint positive immunoreactivity for MMP1 in the extracellular matrix (arrow). Weak positive cytoplasmic reaction (arrowheads) is also seen in few enterocytes and CT cells(x400).

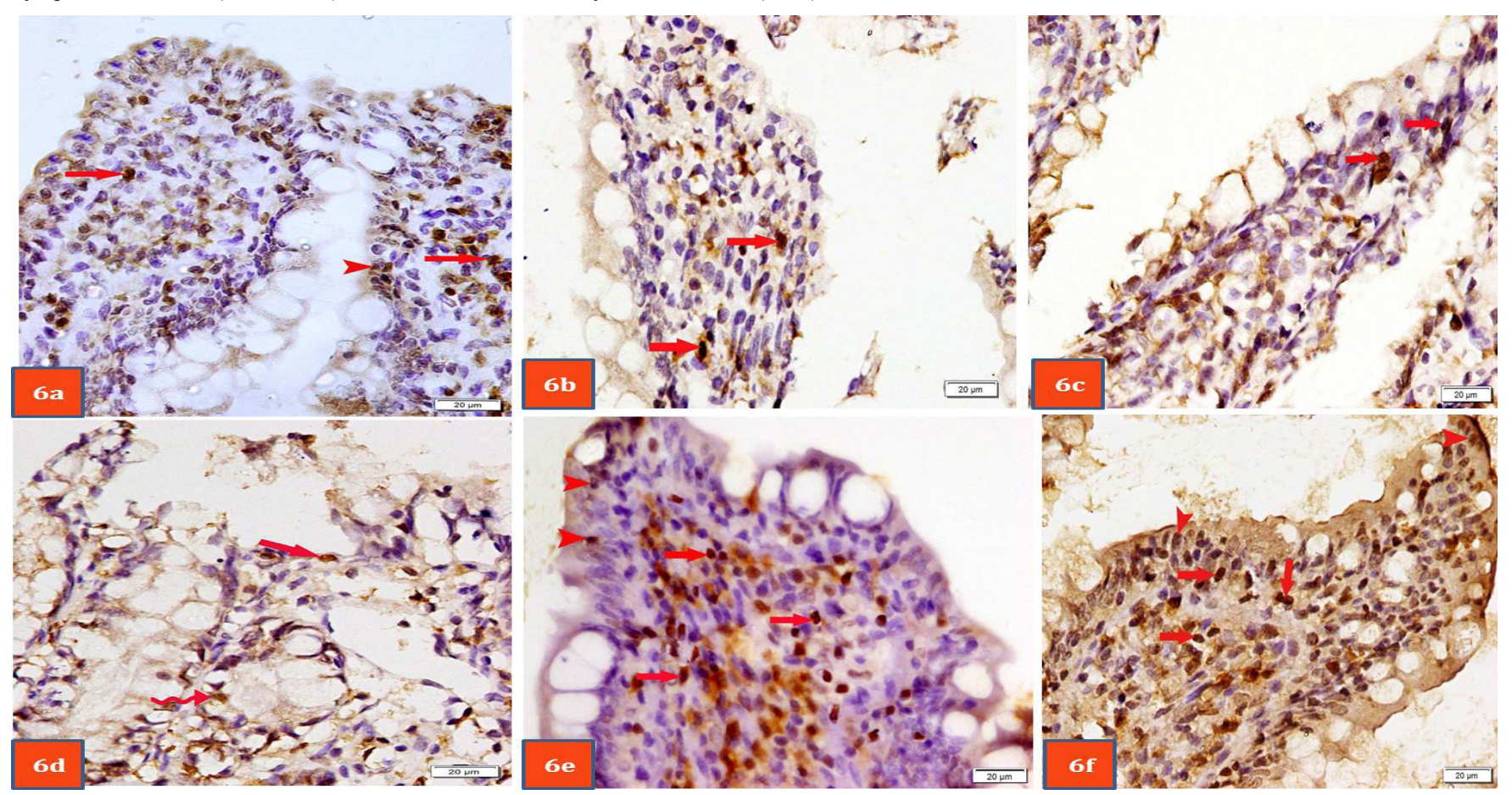

Fig. 6: A Photomicrograph of a section in the ileum of a rat stained with PCNA immunostaining $(6 \mathrm{~A})$ : control group,showing positive nuclear immunoreactivity for PCNA in the villi core (arrows). Few enterocytes with positive immunoreactivity are also seen (arrowhead)(x400).(6B)group IIshowing few cells with positive nuclear immunoreactivity for PCNA in a villus core (arrows) (x400). (6C): group III, the villus core show few cells with positive nuclear immunoreactivity for PCNA (arrows)(x400). (6D): group VI showing few cells with positive nuclear immunoreactivity for PCNA in the core of a disrupted villus (arrow) and in epithelial cells of the crypt (wavy arrow)(x400).(6E):group IVshowing numerous cells in the villus core with positive nuclear immunoreactivity for PCNA (arrows). Some enterocytes with positive immunoreactivity are seen (arrowheads)(x400). (6F):groupV numerous cells in the CT corium of a villus with positive nuclear immunoreactivity for PCNA (arrows). Some enterocytes with positive immunoreactvity are also seen (arrowheads)(x400). 


\section{DISCUSSION}

Crohn's disease is a debilitating lifelong IBD with significant health and economic costs ${ }^{[24]}$. The complications of this disease, such as stricturing and bowel fistula, account for substantial morbidity and health-care costs. Moreover, the validated models to predict complications and to evaluate the effect of the treatment are not available ${ }^{[25]}$.

The present work aimed to develop an experimental model of enteritis (Crohn's disease) using indomethacin in adult female albino rat. Female rats were used in this study as the small intestine of rat is more or less similar to that of human from histological point of view and the incidence of $\mathrm{CD}$ in the females is 1.5 times higher than males ${ }^{[26]}$.

In this study, ileum was chosen as it is the most common area of GIT affected in $\mathrm{CD}^{[27]}$. In addition, indomethacin was chosen for induction of a model of $C D$ as it induced morphological and functional alterations in the small intestine similar to $\mathrm{CD}^{[28]}$

In the current study, ADSCs were used,as these cells have the ability to differentiate into both mesodermal and non mesodermal lineages, similar to bone marrow-derived MSCs (BMSCs). However,ADSCs could be collected in large quantity with minimal morbidity. Moreover, the derivation of ADSCs is easier and less invasive and much more efficient than that of BMSCs. Thus, they are attractive stem cells for regenerative application ${ }^{[2,30]}$.

In the present work, the effect of ADSCs were evaluated after 2 weeks of administration according to a previous study which found that MSCs can colonize in the injured intestine and directly differentiate into mucosal epithelium cells after 14 days $^{[13]}$.

It was mentioned that indomethacin was used to develop a model of enteritis. This model bear close resemblance to $\mathrm{CD}$ in terms of clinical and histopathological feature ${ }^{[31]}$ and carried in part, comparable pathogenesis ${ }^{[32,33]}$. This was obvious on examining the results of group II together with the possible explanations that correlate such model with CD.

In group II (indomethacin induced enteritis), HandE stained ileum sections showed findings that could be attributed to mucosal damage and to the inflammatory reaction following intake of indomethacin ${ }^{[34,35]}$. Similar histopathological features were described in $\mathrm{CD}^{[31]}$.

Tumor necrosis factor (TNF- $\alpha$ ) is a pro-inflammatory cytokine capable of upregulating its own expression as well as the expressions of other genes pivotal to the inflammatory response. Thus TNF- $\alpha$ plays a key role in the in the pathogenesis of indomethacin induced small intestinal injury ${ }^{[36]}$ and the development and progression of $\mathrm{IBD}^{[33]}$.

HandE results of group III and group VI were comparable with each other. The findings of recovery group indicated progressive destruction of the intestinal mucosa with no spontaneous recovery till day 24 of the experiment. Also, the pathology in VI group was still present with no noticeable improvement indicating that DMEM was a non effective treatment ${ }^{[37]}$.

The presence of many mast cells in the villus core of group III could be considered as a part of the inflammatory process that accompanied indomethacin treatment.It might induce prostaglandin deficiency that promotes the mucosal dysfunction and accumulation of inflammatory cells as neutrophils and mast cells, which express chymase enzyme and exacerbate inflammation ${ }^{[38]}$.

In the present work, examined ileum sections in all groups including the control group revealed positive cytoplasmic expression of MMP1.It was mentioned that MMP1has low basal expression in most tissues and can be dynamicalley upregulated in response to cell activation $^{[39]}$. In the current study groups II, III and VI showed significant increase in mean area \% of MMP1 compared to control group.It was reported that the protein level of MMP1 was upregulated in IBD mucosa and in CD and its proteolytic activity was increased in the cells of inflamed epithelium. This elevation might be consideredas response to pro-inflammatory cytokines, such as IL-17A, IL-17F and IL-21 which cause upregulation of MMP1 in intestinal fibroblasts ${ }^{[40]}$. However, in the present work groups III and VI showed significant reduction in mean area $\%$ of MMP1 compared togroup II .This might be due to fibrosis formed during the two weeks longer duration. Reduction in MMP1and increase in tissue inhibitor of metalloproteinase-1 (TIMP-1) was previously detected in fibrosed areas of $\mathrm{CD}^{[41]}$.

In the current work,group II showed non significant decrease in the mean area $\%$ of collagen when compared to control group. This could be explained by loss of normally present collagen fibers with mucosal destruction. While there was significant increase in the mean area \% of collagen in group III and VI when compared to group II.Indomethacin might induce fibrosis, as these groups were left for another two weeks or as an end stage of chronic inflammation ${ }^{[42]}$. Indomethacin could induce achronic model of CDthat associated with fibrosis, in such areas the TIMP-1 level was increased ${ }^{[43]}$ and its expression was inversely correlated with inflammatory cytokine production and mucosal injury ${ }^{[41,44]}$. In the same consequence, increased expression of tissue transforming growth factor beta (TGF- $\beta$ ) in the inflamed intestine, led to increased TIMP-I and decrease MMPI. TGF- $\beta$ activation is a central mediator of fibrosis ${ }^{[45]}$.

Groups II, III and VI, revealed significant reduction in the mean number of PCNA +ve cells compared to control group. This reduction could be explained by ulceration and loss of epithelial cells with destruction of villi and crypts. Similar decrease in PCNA positive cells and proliferative index was found in non-steroidal anti-inflammatory drugs (NSAIDs) induced enteritis model ${ }^{[46]}$. NSAIDs inhibits COX-2 and PGE2 production. This in turn decreases $\beta$-catenin protein signaling and decreasing transcription of proliferation genes in the intestines ${ }^{[47]}$. 
In groups II, III and VI, there was significant reduction in the mean number of goblet cells compared to control group. This could be explained by ulceration of the mucosa and destruction of both villi and crypts by indomethacin. This finding was in accordance, with other authors who attributed this to enterobacterial invasion, upregulation ofinducible nitric oxide synthase (iNOS) expression and overproduction of nitric oxide (NO) in the mucosa ${ }^{[48,49]}$. In addition, the present work revealed significant decrease in the mean optical density of the mucus in group II, III and VI compared to control group. This could be due to the altered mucus barrier and the increased expression of mucin 2 (MUC2), one of mucin family .This MUC2 has reduced oligosaccharide chain length by about $50 \%$ which lead to abnormal function of mucous barrier and play a role in the persistence of $\operatorname{IBD}^{[50]}$.

In the present work, animals treated with ADSCs in group IV and ADSCs-CM in group V showed significant increase in body weight on day 24 compared to group III and VI. Also stool frequency showed remarkable decrease with obvious improvement in its color on day 17 . This difference could be attributed to the therapeutic effect of ADSCs and their conditioned medium respectively.In accordance with this findings, significant decrease in diarrhea and weight loss was recorded afterintravenous injection of ADSCs for treatment of 2, 4, 6-Trinitrobenzene sulfonic acid (TNBS)induced colitis in a murine experimental model of $\mathrm{CD}^{[51]}$ and afterintraperitoneal administrationof BMSC-CM. for treatment of TNBS-induced colitis model ${ }^{[14]}$

Groups IV and V showed remarkable improvement as most villi and crypts restored their architecture with normal distribution of enterocytes and goblet cells. This could be attributed to the therapeutic effect of ADSCs that homed to the injured intestinal areas as detected by fluorescent microscope. Similarly, PKH26-labeledBMSCs relocated to and exhibited local proliferation and transdifferentiation into injured intestinal mucosal cells in a rat model of $\mathrm{IBD}^{[52]}$. Also local application of ADSCs resulted inperanal fistula closure rate in an animal model of $\mathrm{CD}^{[53]}$. MSCs could produce wound healing in TNBS induced colitis rat model through their production of a variety of humoral factors. Prostaglandin E2 (PGE2) is one of the humoral factor secreted from MSCs, It can repolarize pro-inflammatory M1 macrophages into anti-inflammatory M2 macrophages which become involved in inflammation resolution ${ }^{[54]}$. The efficacy of ADSCshas been recently reported in the small intestine of animal models of CD induced by TNBS ${ }^{[55]}$.

It was demonstrated that intraperitoneal administration of amniotic fluid MSC-CM ameliorated dextran sodium sulphate (DSS)-induced colitis in immunodeficient colitis mouse model ${ }^{[56]}$. The anti-inflammatory capacities of ADSC-CM was attributed to the presence of Extracellular vesicles (EVs) which could balance macrophage polarization toward the anti-inflammatory profile ${ }^{[57]}$. Recently, it was found that MSC-CM with its immunomodulatory properties has the potential to reduce inflammatory responses in a mouse model of $\mathrm{IBD}^{[6]}$.
Further enforcement came from PCNA immunostaining results of group IV which showed significant increase in the mean number of PCNA +ve cells when compared to control group, group II and recovery group. It was clarified that the transplanted PKH26-labeled BMSCs in rats subjected to experimental IBD showed a considerable extent of colocalization with PCNA, implicating that they undergo in situ proliferation in the gut ${ }^{[52]}$. However, other author attributed the increase in PCNA + ve cells to intestinal SCs homing to the injured intestinal areas as a response to factors produced in the inflamed tissues and its differentiation into epithelial and immune cells ${ }^{[58]}$.

Meanwhile, group V (ADSC-CM-treated group) showed numerous PCNA +ve cells in the villi and crypts with significant increase when compared to control group, group II and recovery group. In agreement with this result,it was found that the number of PCNA +ve cells was increased at 2 weeks, indicating that MSC-CM maintained a higher cellular activity and enhance early bone regeneration in rabbit model. ${ }^{[59]}$

On comparing both groups IV and V, group V showed significant increase in the number of PCNA + ve cells. This was explained bythe presence of various growth factors like colony stimulating factors (CSF), such as granulocyte colony stimulating factor (GCSF) granulocyte macrophage CSF(GM-CSF) which may recruit various resident stem cells including endothelial progenitors to the site of injury ${ }^{[60]}$.

The meannumber of goblet cells and the mean optical density of mucus in groups IV and V exhibited significant increase when compared to groups II, III and VI. This could be attributed to ADSCs and their CM that improved the mucosal regeneration and reepitheliization and in turn improve goblet cell regeneration as a part of intestinal epithelium. The improvement of goblet cells might be due tovarious factors present in $\mathrm{CM}$ such as keratinocyte growth factor (KGF) that inhibits oxidative stress induced epithelial cell death ${ }^{[61]}$.

Significant decrease in the mean area \% of MMP1 in groups IV and V when compared to groups II, III and VI.In ultra violet-irradiated human dermal fibroblasts,ADSCs reduced MMP1 expression leading to therapeutic benefit in the injured $\operatorname{skin}^{[62]}$. Also the reduction in MMP1wasreferredto TIMP-1 present in MSC-CM stimulated with inflammatory cytokines ${ }^{[63]}$. Interestingly, the reduction in MMP1 in group V was comparable with that in group IV with no significant difference.

Groups IV and V showed significant decrease in the mean area \% of collagen when compared to group III and non significant change when compared to control group. This could be referred to the anti-inflammatory ability of both ADSCs and their CM and to the restoration of the balance between MMP1and TIMP-1. In the same concern, local injection of ADSCs in a rat model of TGF- $\beta 1$ induced urethral fibrosis resulted in significant decrease in collagen type I and III ${ }^{[64]}$. Also, ADSCs had a favorable effect on 
ECM regulation through suppression of TGF- $\beta 1$ signaling in vocal fold fibroblasts during the co-culture of these cells with $\mathrm{ADSCs}^{[65]}$. The efficacy of MSCs in reducing the fibrosis might be secondary to reducing tissue damage ${ }^{[66]}$. The antifibrotic effect of ADSC-CM detected in the current work was in accordance with other study. In such study reduced scar formation was noticed after administration of amniotic MSC-CM.This occurred in bleomycin induced lung fibrosis animal model ${ }^{[67]}$. However, they didn't identify certain factors involved in the reduction of fibrosis. Later, the cytokine array of ADSC-CM was identified, including the presence of chemokines and growth factors $(\mathrm{C}-\mathrm{X}-\mathrm{C})$ ligand 1 (CXCL1), chemokine ligand 3 (CCL3), TIMP-1 and Vascular endothelial growth factor (VEGF)), which promote chemotaxis and angiogenesis ${ }^{[68]}$.

Group V showed non significant difference in the mean area $\%$ of collagen when compared to group IV.Similarlynon significant difference in fibrosis score between the CMtreated group and the MSC-treated groupwas found ina rat model ofCisplatin-induced kidney injury ${ }^{[69]}$.

Therefore, the present work revealed that ADSCs and their $\mathrm{CM}$ are apparently equal in their efficacy. Similarly,MSC-CM was sufficient to improve multiple biomarkers of pathophysiology and to be as effective as transplantation of the corresponding MSCs in a long list of animal models ${ }^{[70]}$.

However, in the applied regenerative medicine, MSC$\mathrm{CM}$ could be superior and more promising than MSCs. It has several advantages including, higher biosafety as its administration has fewer risks of tumor formation. In addition, it has immediate availability as it can be stored, while living cells require extensive time for expansion. Also, it has easier, safer handling and requires less complex medical facilities. Finally, it has lower production costs, since the MSC secretome can be produced in large quantities $^{[71]}$.

\section{CONCLUSION}

1. Two SC doses of indomethacin was effective to induce a rat model of chronic enteritis (Crohn's disease).

2. The ADSCs could reduce tissue damage and fibrosis and enhance proliferation in the intestinal tissues in a rat model of enteritis.

3. The ADSC-CM was as effective as the transplantation of its corresponding ADSCs in mucosal regeneration, this might provide a hope for cell free therapy in degenerative diseases as a new therapeutic strategy.

\section{CONFLICT OF INTEREST:}

There are no conflicts of interest.

\section{REFERENCES}

1. Kanizaj TF and Mijic M (2017): Inflammatory bowel disease in liver transplanted patients. World J Gastroenterol; 23(18): 3214-3227.

2. Chen YL, Chen YT, Lo CF, Hsieh CI, Chiu SY, Wu CY, YehYS, Hung SH, Cheng PH, Su YH, Jiang ST, Chin HJ and Su YC (2016): Early detection of $\mathrm{T}$ cell transfer-induced autoimmune colitis by in vivo imaging system. Sci Rep; 6: 35635-35647.

3. Hakim GD, Soyturk M, Unlu M, Ataca P, Karaman M, Sagol O, Borekci E, and Yilmaz O (2015): Mucosal healing effect of nilotinib in indomethacin-induced enterocolitis: a rat model. World J Gastroenterol; 21(44): 12576-12585.

4. Engels M, Cross RK and Long MD(2017): Exercise in patients with inflammatory bowel diseases: current perspectives.Clin Exp Gastroenterol; 11:1-11.

5. Su J, Xie C, Fan Y, Cheng W, Hu Y, Huang Q, Shi H, Wang L and Ren J (2017): Interleukin- 25 enhances the capacity of mesenchymal stem cells to induce intestinal epithelial cell regeneration. Am J Transl Res; 9(12): 5320-5331.

6. Pouya S, Heidari M, Baghaei K, AsadzadehAghdaei H, Moradi A, Namaki S, Zali MR and Hashemi SM (2018): Study the effects of mesenchymal stem cell conditioned medium injection in mouse model of acute colitis. IntImmunop-harmacol; 54: 86-94.

7. García-Arranz M, Herreros MD, González-Gómez C, de la Quintana P, Guadalajara H, GeorgievHristov T, Trébol J and Garcia-Olmo D(2016): Treatment of Crohn's-related rectovaginal fistula with allogeneic expanded- adipose derivedstem cells: a phase I-IIa clinical trial.Stem Cells Transl Med; 5(11):1441-1446.

8. Volarevic V, Markovic BS, Gazdic M, Volarevic A, Jovicic N, Arsenijevic N, Armstrong L, Djonov V, Lako M and Stojkovic M (2018):Ethical and safety issues of stem cell-based therapy. Int J Med Sci;15(1):36-45.

9. Jiao X, Cai J, Yu X and Ding X (2017): Paracrine activation of the $\mathrm{Wnt} / \beta$-catenin pathway by bone marrow stem cell attenuates cisplatin-induced kidney injury. Cell PhysiolBiochem; 44(5): 1980-1994.

10. Liu B, Ding F, Hu D, Zhou Y, Long C, Shen L, Zhang Y, Zhang D and Wei G (2018): Human umbilical cord mesenchymal stem cell conditioned medium attenuates renal fibrosis by reducing inflammation and epithelial-to-mesenchymal transition via the TLR4/NF- $\kappa$ B signaling pathway in vivo and in vitro. Stem Cell Res Ther; 9(1):7-20. 
11. Pawar AT, Anap RM, Ghodasara JV and Kuchekar BS (2011): Protective effect of hydroalcoholicrRoot extract of rubiacordifolia in indomethacin-induced enterocolitis in rats. Indian J Pharm Sci; 73(2): 250-253.

12. GonçalvesFda C, Schneider N, Pinto FO, Meyer FS, Visioli F, Pfaffenseller B, Lopez PL, Passos EP, Cirne-Lima EO, Meurer L and Paz AH (2014): Intravenous vs intraperitonealmesenchymal stem cells administration: What is the best route for treating experimental colitis? World $\mathrm{J}$ Gastroenterol; 20(48): 18228-18239.

13. Sun T, Gao GZ, Li RF, Li X, Li DW, Wu SS, Yeo AE and Jin B (2015a): Bone marrow-derived mesenchymal stem cell transplantation ameliorates oxidative stress and restores intestinal mucosal permeability in chemically induced colitis in mice. Am J Transl Res; 7(5): 891-901.

14. Watanabe S, Arimura Y, Nagaishi K, Isshiki H, Onodera K, Nasuno M, Yamashita K, Idogawa M, NaishiroY, Murata M, Adachi Y, Fujimiya M, Imai K and Shinomura Y (2014): Conditioned mesenchymal stem cells produce pleiotropic gut trophic factors. J Gastroenterol; 49(2): 270-282.

15. El-AkabawyG,El-KholyW(2014):Neuroprotective effect of ginger in the brain of streprozotocininduced diabetic rats. Ann Anat; 169: 119- 128.

16. Zhang J, Zhi W, Tan M, Chen X, Li X and Deng L (2010): An experimental study on rabbit bone marrow mesenchymal stem cells double-labeled by $\mathrm{PKH} 26$ and 5-bromo-2'-deoxyuridine in vitro and application in cardiac patch. ZhongguoXiu Fu Chong JianWaiKeZaZhi; 24(7): 828-833. (English abstract).

17. Kiernan JA (2001): Histological and Histochemical methods: Theory and Practice, 3rd ed., Arnold publisher, London, New York and New Delhi, 111162 and 219-240.

18. Bancroft JD and Gamble M(2008): Connective tissues and stains. In: Theory and Practice of Histological Techniques, 6th ed., Elsevier Health Sciences, Churchill Livingstone, Edinburgh, London, Oxford, New York, Philadelphia, St Louis, Sydney and Toronto, 135-160.

19. Suvarna KS, Layton $\mathrm{C}$ and Bancroft JD (2012):Immunohis-tochemical techniques. In: Bancroft's theory and Practice of histological techniques, 7th ed., Elsevier Health Science, China, 381-426.

20. Giuffrida P, Biancheri Pand MacDonald TT(2014): Proteases and small intestinal barrier function in health and disease. CurrOpinGastroenterol; 30(2): 147-153.
21. Naryzhny SN (2008): Proliferating cell nuclear antigen: a proteomics view. Cell Mol Life Sci; 65(23): $3789-3808$.

22. Ge X, Leow SC, Sathiakumar D, Stunkel W, Shabbir A, So JB Lomanto D and McFarlane C (2016): Isolation and culture of human adiposederived stem cells from subcutaneous and visceral white adipose tissue compartments. Bio-protocol; 6(22): e2027-e2037.

23. Emsley R, Dunn G and White IR (2010): Mediation and moderation of treatment effects in randomized controlled trials of complex interventions. StatMethods Med Res; 19(3): 237-270.

24. Swarup N, Nayak S, Lee J, PaiRaikar S, Hou D, Sockalingam S and Lee KJ (2017): Forming a support group for people affected by inflammatory bowel disease. Patient Prefer Adherence; 11: 277-281.

25. Kugathasan S, Denson LA, Walters TD, Kim MO, Marigorta UM, Schirmer M, Mondal K, Liu C, Griffiths A, Noe JD, Crandall WV, Snapper S, Rabizadeh S, Rosh JR, Shapiro JM, Guthery S, Mack DR, Kellermayer R, Kappelman MD, Steiner S, Moulton DE, Keljo D, Cohen S, Oliva-Hemker M, Heyman MB, Otley AR, Baker SS, Evans JS, Kirschner BS, Patel AS, Ziring D, Trapnell BC, Sylvester FA, Stephens MC, Baldassano RN, Markowitz JF, Cho J, Xavier RJ, HuttenhowerC, Aronow BJ, Gibson G, Hyams JS and Dubinsky MC(2017): Prediction of complicated disease course for children newly diagnosed with Crohn's disease: a multicentre inception cohort study. Lancet; 389(10080): 1710-1718.

26. Law ST and Li KK (2014): Gender- related differences in clinical course of Crohns disease in an Asian population: a retrospective cohort review. ArqGastroenterol; 51(2): 90-96.

27. Goulart RA, Barbalho SM, Gasparini RG and de Carvalho AC(2016): Facing terminal ileitis: going beyond Crohn's disease. Gastroenterology Res; 9(1): 1-9.

28. Simon H, Fischer T, Almási A and Fischer E (2017): Effects of mesalazine on morphological and functional changes in the indomethacininduced inflammatory bowel disease (rat model of Crohn's disease). PatholOncol Res; 23(1): 41-46.

29. Uzbas F, May ID, Parisi AM, Thompson SK, Kaya A, Perkins AD and Memili E (2015): Molecular physiognomies and applications of adiposederived stem cells. Stem Cell Rev; 11(2): 298-308.

30. Zhang F, Ren H, Shao X, Zhuang C, Chen Y and Qi N (2017): Preservation media, durations and cell concentrations of short-term storage affect key features of human adipose-derived mesenchymal 
stem cells for therapeutic application. PeerJ; 5: e3301- 3322.

31. Shah MK, Wan J, Janyaro H, Tahir AH, Cui L and Ding MX (2016): Visceral hypersensitivity is provoked by 2,4,6-trinitrobenzene sulfonic acid-induced ileitis in rats. Front Pharmacol; 7: 214-226.

32. Michielan A and D'Incà R (2015): Intestinal permeability in inflammatory bowel disease: pathogenesis, clinical evaluation, and therapy of leaky gut. Mediators Inflamm; 2015: $628157-628166$.

33. Lew D, Yoon SM, Yan X, Robbins L, Haritunians T, Liu Z, Li D and McGovern DP (2017): Genetic associations with adverse events from anti-tumor necrosis factor therapy in inflammatory bowel disease patients. World J Gastroenterol; 23(40): $7265-7273$

34. Yamamoto $\mathrm{A}$, Itoh $\mathrm{T}$, Nasu $\mathrm{R}$ and Nishida $\mathrm{R}(2014)$ : Sodium alginate ameliorates indomethacin-induced gastrointestinal mucosal injury via inhibiting translocation in rats. World $\mathrm{J}$ Gastroenterol; 20(10): 2641-2652.

35. Lichtenberger LM, Bhattarai D, Phan TM, Dial EJ and Uray K (2015): Suppression of contractile activity in the small intestine by indomethacin and omeprazole. Am J PhysiolGastrointest Liver Physiol; 308(9): G785-793.

36. Fukumoto K, Naito Y, Takagi T, Yamada S, Horie $\mathrm{R}$, Inoue $\mathrm{K}$, Harusato $\mathrm{A}$, Hirata $\mathrm{I}$, Omatsu $\mathrm{T}$, Mizushima K, Hirai Y, Yoshida N, Uchiyama K, Ishikawa T, Handa O, Konishi H, Wakabayashi N, Yagi N, Kokura S, Ichikawa H, Kita M and Yoshikawa T (2011): Role of tumor necrosis factor- $\alpha$ in the pathogenesis of indomethacininduced small intestinal injury in mice. Int $\mathrm{J}$ Mol Med; 27(3): 353- 359.

37. Li N, Wang P, Ma XL, Wang J, Zhao LJ, Du L, Wang LY, Wang XRand Liu KD(2014): Effect of bone marrow stromal cell transplantation on neurologic function and expression of VEGF in rats with focal cerebral ischemia. Mol Med Rep; 10(5): 2299-2305.

38. Kakimoto K, Takai S, Murano M, Ishida K, Yoda $\mathrm{Y}$, Inoue $\mathrm{T}$, Jin $\mathrm{D}$, Umegaki $\mathrm{E}$ and Higuchi $\mathrm{K}$ (2010): Significance of chymase-dependent matrix metalloproteinase- 9 activation on indomethacininduced small intestinal damages in rats. $\mathrm{J}$ PharmacolExpTher; 332(2): 684-689.

39. Foley CJ and KuliopulosA(2014): A mouse matrix metalloprotease-1a (Mmp1a) gives new insight into MMP function. J Cell Physiol; 229(12): $1875-1880$.
40. O'Sullivan S, Gilmer JF and Medina C (2015):Matrix metalloproteinases in inflammatory bowel disease: an update. Mediators Inflamm; 2015: 964131- 964149.

41. Latella G, Rogler G, Bamias G, Breynaert C, Florholmen J, Pellino G, Reif S, Speca S and Lawrance IC (2014): Results of the 4th scientific workshop of the ECCO (I): pathophysiology of intestinal fibrosis in IBD. J Crohns Colitis; 8(10): 1147-1165.

42. Wynn TA and Ramalingam TR (2012): Mechanisms of fibrosis: therapeutic translation for fibrotic disease. Nat Med; 18(7): 1028-1040.

43. Kawada M, Arihiro A and Mizoguchi E (2007): Insights from advances in research of chemically induced experimental models of human inflammatory bowel disease. World J Gastroenterol; 13(42): 5581-5593.

44. Rogler G and Hausmann M (2017): Factors promoting development of fibrosis in Crohn's disease. Front Med (Lausanne); 4: 96-101.

45. Latella G, Sferra R, Speca S, Vetuschi S and Gaudio E (2013): Can we prevent, reduce or reverse intestinal fibrosis in IBD ? Eur Rev Med PharmacolSci; 17(10) : $1283-1304$.

46. Lai Y, Zhong W, Yu T, Xia ZS, Li JY, Ouyang H, Shan TD, Yang HS and Chen QK (2015):Rebamipide promotes the regeneration of aspirin-induced small-intestine mucosal injury through accumulation of $\beta$-Catenin. PLoS One; 10(7): e0132031- 0132048.

47. Castellone MD, Teramoto $\mathrm{H}$ and Gutkind JS (2006): Cyclooxygenase-2 and colorectal cancer chemoprevention: the beta-catenin connection. Cancer Res; 66(23): 11085-11088.

48. Hayashi S, Kurata N, Yamaguchi A, Amagase K and Takeuchi K (2014):Lubiprostone prevents nonsteroidal anti-inflammatory drug-induced small intestinal damage by suppressing the expression of inflammatory mediators via EP4 receptors. J PharmacolExpTher; 349(3): 470- 479.

49. Takeuchi K, Abe N and Kumano A (2016): Influence of adrenalectomy on protective effects of Urocortin I, a corticotropin-releasing factor, against indomethacin-induced enteropathy in rats. CurrNeuropharmacol; 14(8): 866-875.

50. Cornick S, TawiahA and Chadee K (2015): Roles and regulation of the mucus barrier in the gut. Tissue Barriers; 3(1-2): e982426- e982440.

51. González MA, Gonzalez-Rey E, Rico L, Büscher $\mathrm{D}$ and Delgado M(2009): Adipose-derived mesenchymal stem cells alleviate experimental colitis by inhibiting inflammatory and autoimmune 
responses. Gastroenterology; 136(3):978-989.

52. Qu B, Xin GR, Zhao LX, Xing H, Lian LY, Jiang HY, Tong JZ, Wang BB and Jin SZ (2014): Testing stem cell therapy in a rat model of inflammatory bowel disease: role of bone marrow stem cells and stem cell factor in mucosal regeneration. PLoS One; 9(10): e107891-107900.

53. Ryska O, Serclova Z, Mestak O, Matouskova E, Vesely P and Mrazova I(2017): Local application of adipose-derived mesenchymal stem cells supports the healing of fistula: prospective randomised study on rat model of fistulising Crohn's disease. Scand J Gastroenterol; 52(5): 543-550

54. Miyamoto S, Ohnishi S, Onishi R, Tsuchiya I, Hosono H, Katsurada T, Yamahara K, Takeda H and Sakamoto N (2017): Therapeutic effects of human amnion-derived mesenchymal stem cell transplantation and conditioned medium enema in rats with trinitrobenzene sulfonic acid-induced colitis. Am J Transl Res; 9(3): 940-952.

55. Xie M, Qin H, Luo Q, He X, He X, Lan P and Lian L (2017): Comparison of adipose-derived and bone marrow mesenchymal stromal cells in a murine model of Crohn's disease. Dig Dis Sci; 62(1): 115-123.

56. Legaki E, Roubelakis MG, Theodoropoulos GE, Lazaris A, Kollia A, Karamanolis G, Marinos E and Gazouli M (2016): Therapeutic potential of secreted molecules derived from human amniotic fluid mesenchymal stem/stroma cells in a mice model of colitis. Stem Cell Rev;12(5): 604-612.

57. Lo Sicco C, Reverberi D, Balbi C, Ulivi V, Principi E, Pascucci L, Becherini P, Bosco MC, Varesio L, Franzin C, Pozzobon M, Cancedda $\mathrm{R}$ and Tasso R (2017): Mesenchymal stem cellderived extracellular vesicles as mediators of antiInflammatory effects: endorsement of macrophage polarization. Stem Cells Transl Med; 6(3): 1018-1028.

58. De Francesco F, Romano M, Zarantonello L, Ruffolo C, Neri D, Bassi N, Giordano A, Zanus G, Ferraro GA and Cillo U(2016): The role of adipose stem cells in inflammatory bowel disease: from biology to novel therapeutic strategies. Cancer BiolTher; 17(9): 889-898.

59. Katagiri W, Osugi M, Kinoshita $\mathrm{K}$ and Hibi $\mathrm{H}$ (2015): Conditioned medium from mesenchymal stem cells enhances early bone regeneration after maxillary sinus floor elevation in rabbits. Implant Dent; 24(6): 657-63.

60. Kim J, Lee JH, Yeo SM, Chung HM and Chae JI (2014): Stem cell recruitment factors secreted from cord blood-derived stem cells that are not secreted from mature endothelial cells enhance wound healing. In Vitro Cell DevBiolAnim; 50(2): 146-154.

61. Pawitan JA (2014): Prospect of stem cell conditioned medium in regenerative medicine. Biomed Res Int; 2014: 965849-965852.

62. Son WC, Yun JW and Kim BH (2015): Adiposederived mesenchymal stem cells reduce MMP1 expression in UV-irradiated human dermal fibroblasts: therapeutic potential in skin wrinkling. BiosciBiotechnolBiochem; 79(6): 919-25.

63. Zanotti L, Angioni R, Calì B, Soldani C, Ploia C, Moalli F, Gargesha M, D'Amico G, Elliman S, Tedeschi G, Maffioli E, Negri A, Zacchigna S, Sarukhan A, Stein JV and Viola A (2016): Mouse mesenchymal stem cells inhibit high endothelial cell activation and lymphocyte homing to lymph nodes by releasing TIMP-1. Leukemia; 30(5): 1143-1154.

64. Sangkum P, Yafi FA, Kim H, Bouljihad M, Ranjan M, Datta A, Mandava SH, Sikka SC, AbdelMageed AB and Hellstrom WJ (2016): Effect of adipose tissue-derived stem cell injection in a rat model of urethral fibrosis. Can UrolAssoc J; 10(56): E175-E180.

65. Hiwatashi $N$, Bing $R$, Kraja IandBranski RC(2017):Mesenchymal stem cells have antifibrotic effects on transforming growth factor$\beta 1$-stimulated vocal fold fibroblasts. Laryngoscope; 127(1): E35-E41.

66. Li L, Zhang S, Zhang Y, Yu B, Xu Y and Guan $Z$ (2009): Paracrine action mediate the antifibrotic effect of transplanted mesenchymal stem cells in a rat model of global heart failure. MolBiol Rep; 36(4): 725-731.

67. Cargnoni A, Ressel L, Rossi D, Poli A, Arienti D, Lombardi G and Parolini O (2012): Conditioned medium from amniotic mesenchymal tissue cells reduces progression of bleomycin-induced lung fibrosis. Cytotherapy; 14(2): 153-161.

68. Rathinasabapathy A, Bruce E, Espejo A, Horowitz A, Sudhan DR, Nair A, Guzzo D, Francis J, Raizada MK, Shenoy V and Katovich MJ (2016): Therapeutic potential of adipose stem cellderived conditioned medium against pulmonary hypertension and lung fibrosis. Br J Pharmacol; 173(19): 2859-2879.

69. Abouelkheir M, ElTantawy DA, Saad MA, Abdelrahman KM, Sobh MA, Lotfy AandSobhM (2016):Mesenchymal stem cells versus their conditioned medium in the treatment of cisplatininduced acute kidney injury: evaluation of efficacy and cellular side effects . Int J ClinExp Med; 9(12): 23222-23234. 
70. Vizoso FJ, Eiro N, Cid S, Schneider J andPerezFernandez R(2017): Mesenchymal stem cell secretome: toward cell-Free therapeutic strategies in regenerative medicine. Int J MolSci; 18(9): E1852-1875.

71. Oses C, Olivares B, Ezquer M, Acosta C, Bosch P, Donoso M, Léniz $P$ and Ezquer F(2017):
Preconditioning of adipose tissue-derived mesenchymal stem cells with deferoxamine increases the production of pro-angiogenic, neuroprotective and anti-inflammatory factors: Potential application in the treatment of diabetic neuropathy. PLoS One; 12(5): e0178011- 0178032. 


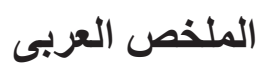

\section{دراسة هستولوجية مقارنة علي تأثير الخلايا الجذعية المستخلصه من النسيج الاهني مقابل الوسط

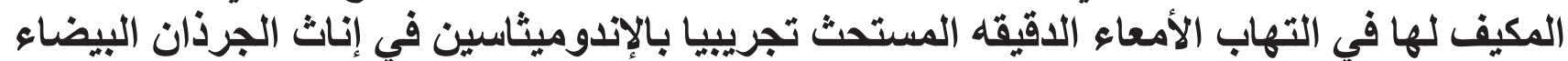 البالغة}

\section{عبير فؤاد عبد المحسن, نجلاع محمد سلامه1, ليلي احمد راشد2, ايمان عباس فرج1,

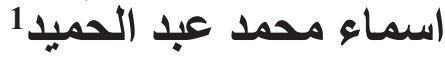 1 قسم الهسولوجيا, 2 قسم الكيمياء الحيويه,كليه الطب,جامعه القاهره,مصر.}

الخلفية: مرض التهاب الأمعاء ، بما في ذلك مرض كرون هو التهاب مناعي مزمن مركب ذو انتشار متز ايد و عدم كفاية العلاج التقليدي. الهُف من العمل: تقييم التأثير العلاجي للخلايا الجذعية المستخلصه من النسيج الدهني مقابل الوسط المكيف لها في نموذج التهاب

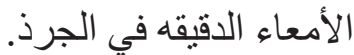

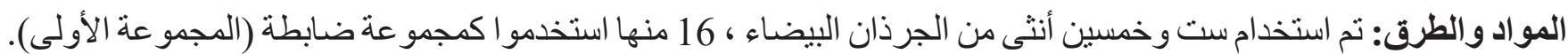

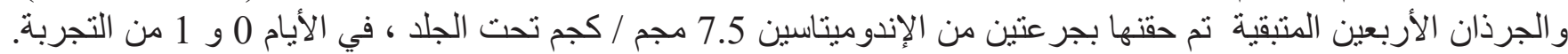

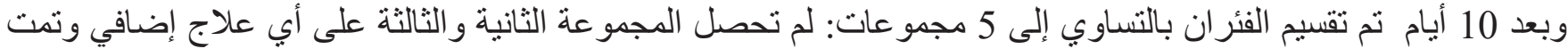
التضحية في الأيام 10 و 24 على التو الي. في حين تم حقن المجمو عةالر ابعهد والسادسه بمليون من الخلايا الجذعيه المستخلصدا

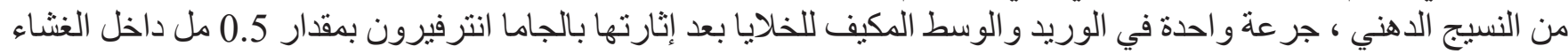

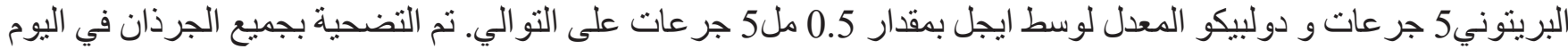

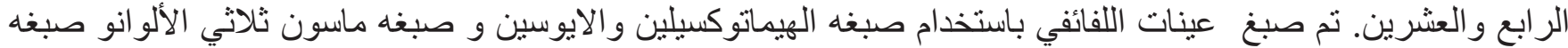

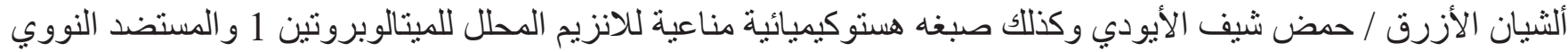

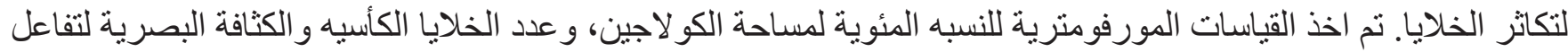

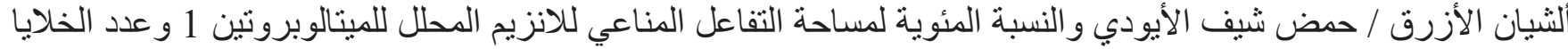
الإيجابية للتفاعل المناعي للمستضد النووي لتكاثر الخلايا وقد تم تحليل البيانات إحصائبا.

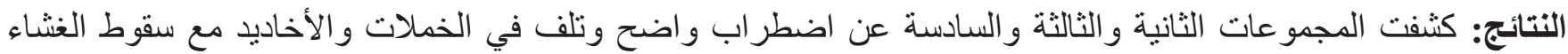

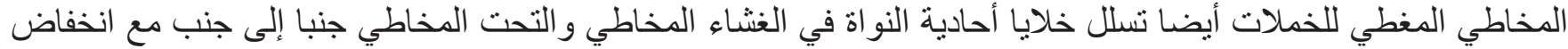

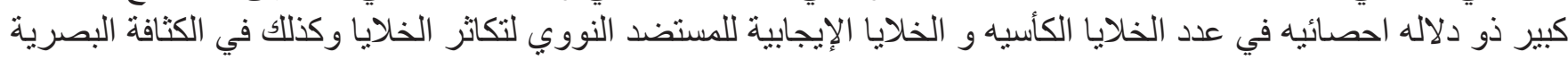

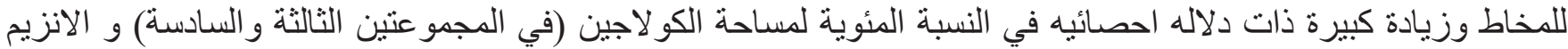
المكسر للميتالوبروتين 1 بالمقارنة مع المجمو عه الضابطه. استعادت المجمو عتان الرابعة و الخامسة تقريبا التركيب النسيجي التهي الطبيعي للخملات و الأخاديد.

الخلاصة: لقد كان استخدام الوسط المكيف للخلايا الجذعيه المستخلصه من النسيج الدهني فعالا مثل استخدام الخلايا الجذعيه

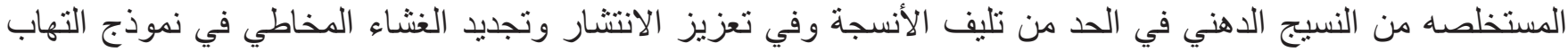
الأمعاء الاقيقه (مرض كرون). الكلمات الدالة:الإندوميتاسين ، التهاب الأمعاءوالدقيقه ، مرض كرون ، الخلايا الجذعيه المستخلصه من النسيج الدهني،الوسط 